archives-ouvertes

\title{
Wage flexibility in regional labour markets: Evidence from Italy and Germany
}

Claudio Lucifora, Federica Origo, Andreas Ammermueller, Thomas Zwick

\section{To cite this version:}

Claudio Lucifora, Federica Origo, Andreas Ammermueller, Thomas Zwick. Wage flexibility in regional labour markets: Evidence from Italy and Germany. Regional Studies, Taylor \& Francis (Routledge), 2010, 44 (04), pp.401-421. 10.1080/00343400903002705 . hal-00588365

\section{HAL Id: hal-00588365 \\ https://hal.archives-ouvertes.fr/hal-00588365}

Submitted on 23 Apr 2011

HAL is a multi-disciplinary open access archive for the deposit and dissemination of scientific research documents, whether they are published or not. The documents may come from teaching and research institutions in France or abroad, or from public or private research centers.
L'archive ouverte pluridisciplinaire HAL, est destinée au dépôt et à la diffusion de documents scientifiques de niveau recherche, publiés ou non, émanant des établissements d'enseignement et de recherche français ou étrangers, des laboratoires publics ou privés. 


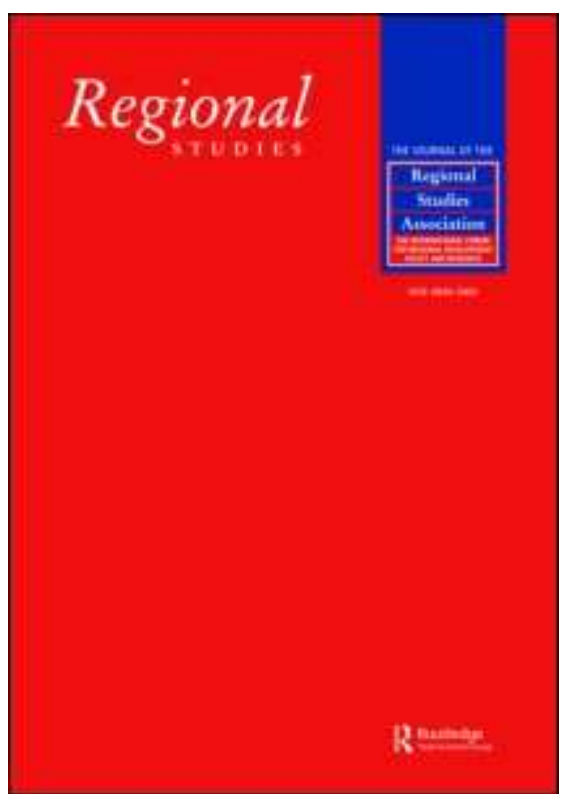

\section{Wage flexibility in regional labour markets: Evidence from Italy and Germany}

\begin{tabular}{|r|l|}
\hline Journal: & Regional Studies \\
\hline Manuscript ID: & CRES-2007-0184.R2 \\
\hline Manuscript Type: & Main Section \\
\hline JEL codes: & $\begin{array}{l}\text { J31 - Wage Level, Structure; Differentials by Skill, Occupation, etc. } \\
<\text { J3 - Wages, Compensation, and Labor Costs < J - Labor and } \\
\text { Vemographic Economics, J6 - Mobility, Unemployment, and } \\
\text { Migration|Regional Labor Markets|Population < R2 - Household } \\
\text { Analysis < R - Urban, Rural, and Regional Economics }\end{array}$ \\
\hline Keywords: & wage curve , regional labour markets, quantile regressions \\
\hline
\end{tabular}

\section{scholarONE" \\ Manuscript Central}




\title{
Wage flexibility in regional labour markets:
}

\author{
Evidence from Italy and Germany ${ }^{1}$
}

Andreas Ammermüller, Federal Ministry of Labour and Social Affairs (BMAS),

Wilhelmstr. 49, 11017 Berlin, Germany (E-mail:

andreas.ammermueller@bmas.bund.de)

Claudio Lucifora, Università Cattolica di Milano, Largo Gemelli 1, 20123 Milano, Italy; Institut Zukunft der Arbeit (IZA) Bonn, Germany; ERMES-Université Paris 2, France (E-mail: claudio.lucifora@unicatt.it)

Federica Origo, Università degli Studi di Bergamo, Via dei Caniana 2, 24127 Bergamo, Italy (E-mail: federica.origo@unibg.it)

Thomas Zwick, Ludwig-Maximilians University (LMU), Ludwigstr. 28/RG, 80539

Munich, Germany and Centre for European Economic Research (ZEW) Mannheim, Germany (E-mail: zwick@bwl.lmu.de)

Received July 2007; in revised form September 2008 


\begin{abstract}
This paper investigates the functioning of regional labour markets in Italy and Germany for different employee groups and regions. We derive theoretical hypotheses on group specific correlations between regional unemployment and individual wages distinguishing between regions. Using micro data matched to local unemployment rates, we specify and empirically test wage equations. For Italy we find no evidence in favour of a relationship between wages and local unemployment. In Germany results appear to be sensitive to model specification and type of employees. In both countries, the reaction of wages to local unemployment varies significantly along the wage distribution, being more sensitive around median quantiles.
\end{abstract}

Key-words: wage curve, local labour markets, quantile regressions

La flexibilité des salaires dans les marchés du travail régionaux:

des preuves provenant de l'Italie et de l'Allemagne.

Ammermuller et al.

Cet article cherche à examiner les rouages des marchés du travail régionaux en Italie et en Allemagne pour des regroupements de salariés et de régions différents. Pour des groupes spécifiques on élabore des hypothèses théoriques sur la corrélation du chômage régional avec les salaires individuels en distinguant entre les régions. A partir des données microéconomiques assorties aux taux de chômage locaux, on précise et teste de façon empirique des équations sur les salaires. Pour l'Italie, il ne s'avère aucune preuve en faveur d'un rapport entre les salaires et le chômage local. En Allemagne, les résultats s'avèrent sensibles à la spécification du modèle et à la catégorie socio-professionnelle. Dans les deux pays, la réponse des salaires au chômage local varie sensiblement le long de la distribution des salaires, étant plus sensible autour des quantiles médians.

Courbe des salaires / Marchés du travail locaux / Régressions des quantiles

Lohnflexibilität in regionalen Arbeitsmärkten: Belege aus Italien und Deutschland

Andreas Ammermüller, Claudio Lucifora, Federica Origo and Thomas Zwick

\begin{abstract}
In diesem Beitrag untersuchen wir die Funktionsweise regionaler Arbeitsmärkte in Italien und Deutschland für verschiedene Arbeitnehmergruppen und Regionen. Wir leiten theoretische Hypothesen über gruppenspezifische Korrelationen zwischen regionaler Arbeitslosigkeit und individuellen Löhnen ab, wobei wir zwischen den
\end{abstract}


einzelnen Regionen unterscheiden. Anhand von auf die lokalen Arbeitslosenquoten abgestimmten Mikrodaten stellen wir Einkommensgleichungen auf und unterziehen sie einer empirischen Überprüfung. Für Italien konnten wir keine Anzeichen für eine Beziehung zwischen Löhnen und lokaler Arbeitslosigkeit feststellen. In Deutschland scheinen die Ergebnisse von der Spezifikation des Modells und von der Art der Arbeitnehmer abzuhängen. In beiden Ländern variiert die Reaktion der Löhne auf die lokale Arbeitslosigkeit signifikant entlang der Lohnverteilung, wobei im Bereich der medianen Quantile die höchste Sensitivität festzustellen ist.

Key-words:

Lohnkurve

Lokale Arbeitsmärkte

Quantile Regressionen

Flexibilidad de salarios en los mercados laborales regionales: el ejemplo de Italia y Alemania

Andreas Ammermüller, Claudio Lucifora, Federica Origo and Thomas Zwick

\begin{abstract}
En este artículo analizamos el funcionamiento de los mercados laborales regionales de Italia y Alemania para diferentes grupos de empleados y regiones. Distinguiendo entre las distintas regiones, derivamos hipótesis teoréticas sobre las correlaciones de grupos específicos entre el desempleo regional y los diferentes salarios individuales. Usando micro-datos adaptados a las tasas de desempleo local, especificamos y comprobamos empíricamente las ecuaciones de salarios. Para Italia no observamos muestras a favor de una relación entre salarios y desempleo local. En Alemania los resultados parecen ser sensibles a la especificación del modelo y el tipo de empleados. En ambos países varía significativamente la reacción de los salarios al desempleo local en la distribución de salarios siendo más sensible en los cuantiles medios.
\end{abstract}

Key-words:

Curva salarial Mercados laborales locales Regresiones cuantiles

JEL Codes: J3, J6, R1 


\section{Introduction}

The OECD points at Germany and Italy as prime examples in Europe for large and persistent regional disparities on the labour market (OECD, 2000). In both countries there is a clear correlation between net migration and unemployment rates by region. However, the scale of movement is not sufficient to act as a rapid adjustment mechanism. Although both countries are similar in their large and persisting regional unemployment disparities (BADDELEY et al., 1998) and rather inflexible labour markets, labour market attachment in the "weaker part" of the countries (i.e. the South in Italy and the East in Germany) differs diametrically. While participation in East Germany, especially of females, is higher than in the West and does not respond to changes in the unemployment rate, participation in the South of Italy is lower than in the North and especially female participation reacts to changes in the unemployment rate. As the labour market attachment of particular groups is key to a proper understanding of the adjustment mechanisms on the labour markets, a comparative investigation of both countries seems especially promising.

This paper aims at investigating wage flexibility in regional labour markets in Germany and Italy in more detail than before. In particular, we estimate the link between individual wage levels and regional unemployment rates, the so-called wage curve (BLANCHFLOWER and OSWALD, 1990). While there is an abundance of wage curve estimations, very few contributions try to compare countries by looking at regional differences in the slope of the wage curve across groups of workers and between 
depressed and booming regions and try to explain those differences (CARD, 1995; NIJKAMP and POOT, 2005). These differences are key, however, to a better understanding of the functioning of regional labour markets.

This paper mainly stresses the heterogeneity of the wage curves for different employee groups in depressed and booming regions (East/West Germany and North/South Italy). In addition, we show for the first time differences in the wage curve along the wage distribution. Finally, we attempt to derive some hypotheses why we should observe different wage curves: We provide a theory based on differences in female labour participation behaviour and differences in bargaining and monopsony power for employees with different educational backgrounds in both parts of the countries. In addition, we provide evidence from wage quantile estimates which has not been done before. We derive the result that elasticities tend to be higher in the middle of the earnings distribution by referring to monopsony and collective bargaining as reasons why elasticities are lower in lower quantiles, while higher geographical mobility of workers in the upper quantiles (better education) is the other part of our argument. We also note that if there is a substantial underground economy, a negative shock increases unemployment but also the underground economy - providing mostly low skilled jobs thus exerting less pressure on wages in the lower part of the wage distribution.

The paper is organised as follows. In section 2, we review the theoretical considerations underlying the functioning of regional labour markets. Section 3 presents the Italian and German institutional setting and offers an overview of the main stylised facts concerning the wage-unemployment relationship at the regional level in the two countries. Section 4 contains our empirical approach and a description of the data sources. The estimates of the wage-regional unemployment relationship for different 
employee groups are presented in section 5. The last section contains the concluding remarks and some policy implications.

\section{Differences in the Relation between Individual Wages and Regional}

\section{Unemployment}

The relationship between unemployment and wages has often been the object of controversies. According to the textbook analysis of labour markets, regional unemployment may result from asymmetric shocks affecting the demand or the supply of labour and from wages failing to adjust to the market clearing level. Here, the relationship between wage and unemployment is a temporary phenomenon characterising the adjustment process in the labour market. Alternatively, when reference is made to those theories in which the existence of imperfect competition on either product or labour markets (or both) is assumed, unemployment may well be considered as a key feature of the equilibrium. In other words, an "equilibrium" relation between wages and (regional) unemployment might exist (LAYARD et al., 1991; BLANCHFLOWER and OSWALD, 1990, 1994a,b). Differences in this relationship might arise for different reasons. For example if institutional constraints are binding, such as negotiated wages under national collective bargaining, depressed and booming regions may exhibit a different pattern (BRUNELLO et al., 2001; BANDE et al., 2007). In particular, negotiated wages may follow the wage-curve hypothesis in regions with low unemployment, and may not react to changes in unemployment in regions where unemployment is high (BÜTTNER, 1999). Alternatively, differences may arise from a different labour market attachment when there are adverse shocks across regions and between countries. In this respect, BADDELEY et al. (1998) show an important 
difference in the reactions of the labour force to changes in unemployment between Italy and Germany: while in Italy an increase in unemployment leads mainly to a reduction in the number of active labour market participants, for Germany a larger positive impact is found during upswing phases.

The main focus of this paper is to provide evidence that the long run "equilibrium" relation between the level of wages and the level of regional unemployment may differ across countries and among regions and employee groups within countries, particularly by gender, skill level, position in the wage distribution. We therefore first consider some theoretical explanations for differences in wage flexibility in the presence of unemployment between these employee groups and then draw some hypotheses for Italy and Germany.

Regarding gender differences, there is evidence showing that female labour participation reacts stronger during the business cycle than male labour participation (KILLINGSWORTH, 1983; MORRISON et al., 2006). Also, women are usually tiedmover and follow their male counterpart in their regional choices of jobs (FAGGIO and NICKELL, 2005). Finally, females are more likely to be working in a residual sector where labour markets are more competitive and less influenced by union wage setting (JANSSENS and KONINGS, 1998). We expect that these effects might lead to a smaller correlation between regional unemployment and female wages (in comparison to male wages). Participation decisions may also depend on institutional and cultural factors, in particular in the two countries of our analysis. In East Germany before reunification, employment played a central role in social life. Female participation rates were exceptionally high because the state provided a powerful system of day care for children and stimulated the quick return of mothers to their workplaces (SINN and 
SINN, 1991). Moreover, relatively cheap housing and regional services make it rather expensive for many to move from East Germany to other regions with higher wages and better labour market prospects. On the other hand, in the South of Italy the labour market attachment - especially of females - is low and highly reactive to regional labour market conditions. The lower attachment of women may be explained both by cultural reasons and by the lack of job opportunities - women prefer not to participate to take care of their family and/or to increase the probability of their husband to find/hold a job. The relatively high attachment of men in the South may then be explained by the fact that they are likely to be the only worker in the household, hence they need to stay in the labour market to sustain the family.

Economic theory also suggests that wage elasticity to regional unemployment may vary by skill level and along the wage distribution, but theoretical predictions are not unambiguous. A reason for a different impact of aggregate unemployment on qualification-specific employment rates might be that firms lay off their employees in inverse order of seniority or smooth employment of those workers with high turnover costs, while workers who are more easily replaced suffer job losses during depressions (MINCER, 1991; VAN OURS and RIDDER, 1995; CARD, 1995). Since labour turnover costs increase with human capital, high skilled workers should be characterised by lower turnover rates over the business cycle. One consequence of the higher employment security of better qualified employees during the business cycle is the stronger reaction of their higher wages to macro-economic shocks (JOHANSEN, 1999; AMMERMÜLLER et al., 2008). On the other hand, the higher educated employees are more geographically mobile and therefore should be less exposed to changes in local labour market conditions (MORRISON et al., 2006), while firms can use their local 
wage monopsony power on less skilled workers. Firms may also be characterised by implicit contracts with their employees who have acquired firm-specific human capital and keep their wages stable during the business cycle. A final argument for a higher wage responsiveness of unskilled as compared with skilled employees is that the job opportunities for low-skilled employees and their expected cost of job losses increase more strongly with unemployment and this might make them more accepting of wage cuts in high unemployment periods (LAYARD et al., 1991).

Changes in regional unemployment may also produce different wage effects along the wage distribution. Employees at the lower end of the wage distribution rather leave the labour market than accept lower wages if unemployment increases, thus implying a weaker correlation between unemployment and wages for low wage quantiles. This phenomenon is especially prominent in Germany and Italy because the replacement ratio of unemployment and social benefits for these groups are high there. Moreover, economy-wide or industry collective contracts are usually binding for low paid workers, while individual or enterprise specific contracts are more widespread for employees at the high end of the wage distribution (BÜTTNER and FITZENBERGER, 1998). These aspects seems particularly noticeable in the case of Italy, where wages are mainly negotiated at the industry level and, despite recent reforms in the wage bargaining system, a marginal role is still played by regional bargaining aimed at redistributing productivity gains, mainly in small and Southern firms (CASADIO et al., 2005) ${ }^{2}$. Finally, people with higher abilities given a certain qualification level (i.e. workers higher up the conditional wage distribution) have a lower unemployment risk. In a boom phase wages of high paid employees increase stronger than those of low paid workers because there is competition among firms about these employees, while the employees 
for the new jobs down the wage distribution can be recruited from unemployment. These arguments imply that the wages of employees at the lower end of the wage distribution should be less sensitive to regional unemployment changes.

On the contrary, firms can also react by reducing hiring standards to attract lower ability employees in boom phases instead of increasing wages (REDER, 1955). This keeps wages of employees at the top end of the wage distribution relatively stable, while there is a higher wage cyclicality down the wage distribution mainly for job entrants because this group of employees finds more attractive and better paid jobs than usually (DEVEREUX, 2004). Another argument for higher wage elasticity for employees at higher quantiles of the wage curve is the shirking model presented by BLANCHFLOWER and OSWALD (1994a). If shirking by employees at the high end of the wage distribution generates high losses for firms, one might observe a stronger elasticity of the wage curve for this group of employees. Nonetheless, the effect of changes in regional unemployment at the high end of the wage distribution is less clear and probably asymmetric. These employees should in fact face a stronger increase of bargaining power than the employees at the lower end if unemployment decreases. On the other hand, employees at the high end of the wage distribution are regionally more mobile and therefore can avoid wage cuts during regional recessions. In the middle of the wage distribution it is more costly (than for low paid workers) to withdraw from the labour market if wages decline during a recession, while it may not be worth it to move to a different region (compared with employees in the high part of the wage distribution).

Other institutional differences may play a crucial role in influencing the relation between regional unemployment and regional wages. More specifically, strict labour 
and product market regulation could induce some firms to operate in the underground economy, where part of the adjustment can take place when regional labour market conditions change. In other words, when regional unemployment increases some workers may find a (presumably lower paid) job in the irregular sector, thus leaving wages in the formal sector virtually unchanged. A different incidence of the underground economy across regions may explain why the wage curve is more evident in some areas than in others (namely, in those where the underground economy is less relevant). The effect of the underground economy on the wage curve may be particularly important in (the South of) Italy, which is among the OECD countries characterised by the highest incidence of the underground economy (LUCIFORA, 2003). We therefore hypothesise that the wage curve in Italy is weaker than in Germany.

Our theoretical considerations suggest that there should be different wage curves for different groups and regions. Below, we demonstrate that indeed the wage curve is stronger in Germany than in Italy, for (German) females and for people in the middle of the wage distribution.

\section{The Institutional Setting and Stylised Facts}

\subsection{Institutional Setting}

Both Italy and Germany are characterised by relevant unemployment differences across regions, coupled with quite centralised wage bargaining systems and strict employment protection legislation.

In Italy the debate on the existence of significant differences in regional labour market conditions has a long standing tradition and has been associated with a long sequence of policy measures and "special" regimes. The latter have regarded the more 
disadvantaged areas of the country (mainly located in the Southern regions), the socalled "Mezzogiorno". In Germany the largest regional differences on the labour market are instead observed between the former East and West German states. Also within the North of Italy and West Germany there are persistent regional differences, but they are relatively small in comparison to, respectively, the North-South and the East-West divide (OECD, 2000).

The persistent differences between East and West Germany are related to several institutional decisions during the re-unification process in 1989 and 1990 (SINN and SINN, 1991). The closing of the wage gap proceeded faster than improvements in labour productivity in East Germany, making production in traditional firms too costly and leading to massive de-industrialisation. Mainly subsidiaries of West German or international firms with established brands (and their related market and price setting power), experience in marketing and export survived the first half of the nineties. The main problem of start-ups by regional entrepreneurs was a lack of capital. The massive structural break, incurred by the bankruptcy of traditional firms and low investments from West Germany and abroad, led to a high and persistent unemployment.

Usually two arguments are raised for the rapid wage increases in East Germany. First, unions and politicians argued that without comparable wages in both parts of the country, there would be a brain-drain and a dramatic migration from East to West. Several commentators predicted a "German Mezzogiorno" if the living conditions would not converge quickly. Furthermore, wages and social benefits were seen as crucial parts of the living conditions that should be comparable in all regions of Germany by the constitution. Second, West German firms had no interest in a low-cost 
competition with comparable institutional rules and infrastructure within the same economy.

In addition to relatively low labour demand, incentives to re-enter the labour market are lower in East Germany than in the West because the generous West German social benefits system was almost fully transferred to the Eastern part of the country, while productivity, labour demand and living costs are lower.

The consequences are that investments and economic growth in East Germany are lower than in West Germany since 1995 and unemployment is persistently higher. Migration from East to West Germany is confined to young and relatively well-educated people and this reduces the attractiveness of the labour force in the East. Productivity is still only 70 percent of the level in West Germany. The net transfers of more than 80 billion $€$ per year from West to East are mainly spent on consumption and welfare benefits instead of investments. The policies to improve the situation do not promise a quick fix of the problems, but they could at least reduce the East-West divide somewhat. ${ }^{13}$

In Italy we don't observe in the last decades such a "shock" like re-unification in Germany, but several and continuous attempts have been made to promote economic convergence between the North and the South of the country. Convergence in income levels across areas was mainly pursued through national collective bargaining and (after 1968) through the abolition of the so-called "wage grids" (which were used to set wage differences in collective negotiations across areas). At the same time, faced with increasing gaps in productivity levels and a different degree of competitiveness between Northern and Southern regions, a substantial flow of transfers and subsidies (mainly in the form of cuts in social security contributions) was directed towards firms operating in 
the more depressed areas. Despite of these measures, a progressive polarisation of labour market conditions in different areas of the country has been emerging over the last decades, characterised by growing productivity and unemployment differentials and the reduction in (internal) migration flows - from the South to the North of Italy (ATTANASIO and SCHIOPPA, 1992). FAINI et al. (1997) investigated the causes behind this puzzle and found that this can be explained by a combination of demographic factors (particularly an ageing population and rising women employment rates, which make it more difficult for the household to move), high mobility costs and inefficiency in the job matching process (essentially driven by the inefficiency of monopolistic public employment services). They also pointed out that family support may reduce youth mobility more in terms of assistance in the job-searching process (compared to other EU countries, Italian unemployed tend to rely much more on family ties and informal networks to find a job) rather than by financing long spells of unemployment at home. Furthermore, the relationship between wages and unemployment has been generally weak, with significant differences existing between small and large firms and between Northern and Southern regions (BODO and SESTITO, 1994; FAINI, 1995; CASAVOLA et al., 1995; BRUNELLO et al., 2001; MAIDA et al., 2005).

In the early Nineties a significant wave of reforms (i.e. elimination of the wage indexation mechanism - the scala mobile - and seniority premia; the tripartite incomes policy agreement in July 1993) was introduced to allow both employment and wages to be more flexible and reactive to productivity and business conditions. ${ }^{4}$ In particular, the 1993 Income Agreement introduced a two-tier bargaining system (instead of the previous fragmented and uncoordinated system) aimed at preserving the purchasing 
power of wages without creating inflation pressure. Wages are in fact bargained at the industry level, taking into account inflation targets set by the Government. Further productivity gains can then be redistributed through additional wage bargaining at the regional/company level, mainly through performance related pay schemes.

Together with the progressive reduction of public transfers and subsidies to firms operating in the South, these reforms may have contributed to make wages more sensitive to regional labour market conditions (DELL'ARINGA et al., 2007). Further contractual flexibility introduced by recent labour market reforms (such as assisted temporary employment with the so called "Treu Package" in 1997 and other forms of temporary contracts - including staff leasing, job sharing and on call jobs - with the "Biagi law" in 2003) should also produce similar effects (i.e., a closer link between wages and unemployment) at the regional level.

\subsection{Some Stylised Facts}

In both Italy and Germany, unemployment rates show considerable differences across regions. ${ }^{5}$ Besides the traditional divide between unemployment rates in the North of Italy (3-8 percent) and the South of Italy (about 15-20 percent), and Western Germany (6-12 percent) and Eastern Germany (14-21 percent), there are noticeable differences also among neighbouring regions. These differences underline the existence of low geographical worker mobility and exhibit a significant persistence over time (FAINI et al., 1996).

In the previous sections we have already noted that there might be large and persistent differences in the labour market attachment between Italy and Germany and especially between the two economically weaker parts of the countries, South Italy and 
East Germany. Indeed, we find a relatively high labour market participation in East Germany, regardless of the higher regional unemployment rates, while the situation is quite the contrary in South Italy, where unemployment and participation display a negative correlation (see Figure 1$)^{6}$. In both countries, male and female participation rates are highly correlated. Female labour participation is higher in East than in all West German regions, while male labour participation is comparable in both parts of the country.

(Figure 1 around here)

Turning to regional wage differentials: wages in most Northern Italian regions are 510 percent higher than the national average, but some heterogeneity exists also within each area. In some Southern regions relatively high wages are registered at least in one of the years considered. Over time no clear-cut trends seem to emerge (since both some Northern and Southern regions have been improving their relative position), even if for most of the South wage differentials have been widening in the last decade.

In Germany wage levels were more than 15 percent lower than the national average in the Eastern parts and there was almost no convergence process between 1996 and 2000. The only exception is the federal capital Berlin. Its former western part belongs to the western collective bargaining area. This is important because most wages belong or at least are oriented to the collective bargaining accord struck separately for different regions. While it was originally planned to increase the Eastern collectively bargained wages quickly to the Western level, still Eastern contractual wages are lower than Western ones (albeit higher than the relative productivity in most firms in East 
Germany). In addition, a much higher share of establishments does not take part in collective bargaining in the East and pays wages lower than the bargained wage or opts out of paying the full wage on the basis of an acute economic emergency. This means that wage agreements can differ between regions, wage agreements can allow for local wage differences, and employers might pay more than the negotiated wage in Germany (BÜTTNER, 1999).

\section{Empirical Analysis}

In the empirical literature the wage curve has often been specified (and estimated) as a reduced form assuming the (regional) unemployment variable as exogenous. However, if the wage curve is interpreted as a structural relation, it is necessary to introduce some assumptions concerning how the long run market equilibrium is determined: namely, a relation written either in terms of a price equation or of a labour demand curve is necessary.

The model can be written as follows:

$$
\begin{aligned}
& w_{j}=\phi\left[f\left(U_{j}\right), \rho_{j} \mid X_{j}\right] \\
& U_{j}=\varphi\left(w_{j}, \rho_{j}, \sigma_{j} \mid Z_{j}\right) \\
& E\left(\Gamma_{j}\right)=\Gamma^{*}
\end{aligned}
$$

where $j$ indexes the area $(\rho)$ - this means that $\rho_{j}$ is the regional fixed effect $-w$ is the wage level, $U$ the regional unemployment, $\sigma$ a demand shock, and $X$ and $Z$ are two vectors of control variables (i.e. respectively for the wage curve [1] and the price/labour demand curve [2]). The model is closed by the "no-migration condition" according to which, in equilibrium, expected utility $\mathrm{E}\left(\Gamma_{\mathrm{j}}\right)$ should be equalised across areas. 
The identification of equation [1] can be obtained either by assuming that only variations in $\sigma$ occur (i.e. idiosyncratic shocks affect only the demand), or by using Instrumental Variables techniques to instrument regional unemployment ${ }^{7}$. A further option is to consider a recursive model, in which wage levels only depend on past unemployment. It should be noted that, from an empirical point of view, the relation between wages and local unemployment can be estimated using either time-series data (at the state or regional level) or micro-data (i.e., with wages and other workers' characteristics measured at the individual level). BLANCHFLOWER and OSWALD (2005) pointed out that there might be at least four different views in the economics literature that can be used to justify the nature of this relation. The most traditional (and famous) one is called the Phillips curve, which states the existence of a negative relation between the rate of wage growth and the level of the unemployment rate. Usually estimates of the Phillips curve are based on aggregate time series data. The second view relies on the concept of compensating differentials and postulates the existence of a positive spatial correlation across areas between the level of wages and the level of local unemployment: if unemployment is an unpleasant attribute, high unemployment regions (or industries) should pay higher wages to attract workers and to compensate them for the disutility of working there (HARRIS and TODARO, 1970) ${ }^{8}$. The focus of this theory is then the relation of the (long run) level of wages and the (long run) level of unemployment between regions and it can be empirically tested using aggregated data at the regional (or industry) levels.

A third view is embedded in models of the labour market with imperfect competition (LAYARD et al., 1991). If wages are negotiated by unions and prices are determined by firms with market power, then the equilibrium relationship between the level of wages 
and the level of unemployment may be captured by the interactions of a wage equation (i.e. labour supply) and a price setting equation (i.e. labour demand). Empirical estimates of these models are usually aimed at measuring the NAIRU on the basis of aggregated data.

Finally, a last view, which is the focus of our empirical analysis, assumes the existence of a negative relationship between wages and unemployment 'within' regions (the so-called wage curve). In this context, the underlying hypothesis is that local labour markets are somewhat segmented and that economic shocks to one region will - ceteris paribus - mainly have an impact on the level of local wages. This relation is corroborated by a number of economic models. For example in terms of efficiency wage models, low unemployment requires higher wages to deter workers' shirking or to reduce labour turnover. Alternatively, when wages are determined through collective bargaining, the unemployment rate plays the role of moderating trade unions' wage aspirations: the higher the number of jobless individuals the lower the bargaining power of unions. Regardless of the theory of non-competitive labour markets, the main result, in terms of wage-unemployment equilibria, is that (local) unemployment and the level of wages, within each area, will be negatively correlated ${ }^{9}$.

Empirical estimates of the wage curve are usually based on highly disaggregated data, in order to control for heterogeneity in regional labour markets both in terms of workers' (i.e. age, education, work experience, etc.) and firms' characteristics (i.e. size, level of unionisation, profitability, sector etc.). However, the unemployment rate usually refers to the area where individuals work (or firms are located). The use of variables at different levels of disaggregation may lead to biased estimates if all the individuals who work in the same region share some common factors. More precisely, the estimates of 
the more aggregated variable (i.e., the unemployment rate) present lower standard errors. From a statistical point of view, this can overestimate the importance of regional unemployment in influencing individual wages (MOULTON, 1986, 1990).

To tackle the problem there are a number of options available. First, estimates can be obtained using cell means (conditional or not on a given set of characteristics) for the more disaggregated variable, where the actual degrees of freedom are determined by the more aggregated variable (BLANCHFLOWER and OSWALD, 1994a). Second, a "two stage" procedure has been used by BLANCHARD and KATZ (1997). In the first step, individual wages are regressed on personal and job characteristics and on region by year fixed effects, which are used as proxies for the regional wage. Once these are estimated, they are regressed against regional unemployment, regional fixed effects and year fixed effects We need the latter variables in order to seize all permanent components of the relationship between wages and unemployment and leave only the transitory components to the unemployment coefficients (GARCIA and MONTUENGA, 2003). This model is estimated using standard errors from the first stage regression as weights ${ }^{10}$.

\subsection{An Econometric Specification for the Wage Curve}

The specification adopted in most empirical studies of the wage curve is as follows (compare BELL et al., 2002):

$$
w_{i j t}=\rho_{j}+\tau_{t}+\phi f\left(U_{j t}\right)+\boldsymbol{\beta}^{\prime} \boldsymbol{X}_{i j t}+\varepsilon_{i j t}
$$

where $w_{i j t}$ is the $(\log )$ wage paid to individual $i$ in the region $j$ at time $t ; f\left(U_{j t}\right)$ is a nonlinear transformation of the regional unemployment rate; $\rho_{\mathrm{j}}$ and $\tau_{\mathrm{t}}$ are, respectively, area 
and time fixed effects, while $X_{i j t}$ is a vector of additional factors that may influence wages; finally, $\phi$ and $\beta$ are the parameters to be estimated and $\varepsilon_{i j t}$ is the error term.

Equation [4] assumes the existence of a long run equilibrium relation between wage levels and regional unemployment rates. The expected sign of this relationship - as discussed in a previous section - is negative $(\phi<0)$.

Different dynamic models, which can be related to equation [4] above, have been used in the literature on the wage curve, the exact specification depends on the nature and disaggregation of the data (for a detailed survey see MONTUENGA and RAMOS, 2005). The simplest model is characterized by the introduction of a lagged wage in equation [4]. BLANCHARD and KATZ (1999) provide a theoretical explanation for the presence of such a term by proposing a macroeconomic model in which real wages respond with some inertia to both productivity and (local) unemployment changes. Equation [4] also can be estimated, using regional-state data, with first differences (CARD, 1995). With specific parameters restrictions, simple dynamic specifications of model [4] - as the ones discussed above - also allow us to empirically discriminate between a Phillips curve and a wage curve characterisation of the wage determination process. Moreover, a more flexible specification can also incorporate an Error Correction Mechanism (HAMILTON, 1994). Hence, in the empirical analysis we use the following specification:

$$
\Delta w_{i j t}=\rho_{j}+\tau_{t}+\alpha w_{i j t-1}+\gamma_{1} f\left(U_{j t-1}\right)+\gamma_{2} \Delta f\left(U_{j t}\right)+\beta X_{i j t}+\varepsilon_{i j t}
$$

where variable definitions are the same as in [4], while wage adjustment to local unemployment shocks is characterised by some inertia (captured by lagged wages) and depends on both the lagged level of the local unemployment rate and its change. ${ }^{11}$ Notice that the above specification still describes the long run equilibrium, between the 
level of wages and the level of regional unemployment, but it also allows for an Error Correction Mechanism, such that deviations from the long run equilibrium (i.e. due to wage inertia) can also have an impact on wage formation. ${ }^{12}$ On the regional level our data are a panel. By taking differences, we indeed sort out unobserved differences between regions and years (such as natural amenities, macro-economic shocks etc.).

Furthermore, under simple parameter restrictions different hypotheses can be tested: when $\alpha=-1$ and $\gamma_{1}=\gamma_{2}$, equation [5] reduces to the standard specification of the wage curve of equation [4]. Also, if $\alpha \approx 0$ the relationship becomes a more traditional augmented Phillips curve; alternatively, when $0<|\alpha|<1$, we get a more standard partial adjustment wage equation $^{13}$

\subsection{Data}

In the empirical analysis for each country we use a matched data set obtained by merging - at the regional level - individual records on wages, personal and firm characteristics as well as geographical location with unemployment rates and other regional labour market features reported in the Labour Force Survey (LFS). Given the aim of our analysis, we restrict our sample to non-agricultural employees working in the private sector, thus excluding self-employed and public sector employees. The structure of the data in Italy and Germany are very similar because they contain representative individual information and official data on regional unemployment. In addition, we construct the variables on earnings, experience and schooling in a comparable way.

In the case of Italy, we use micro-data from the waves 1991-2004 of the Bank of Italy's Survey on Households Income and Wealth (SHIW), focusing our attention on the last decade ${ }^{14}$. Detailed information on personal and job characteristics of a 
representative sample of around 4000 private employees (for each wave) is available. Personal characteristics include gender, age, years of education and marital status, while job characteristics include economic sector, years of work experience, tenure, occupation (blue collars, white collars and managers), type of contract (whether full or part-time) and number of hours worked. Individuals are located according to their administrative region of residence (19 regions), covering the entire national territory ${ }^{15}$. The survey provides direct information on annual net wages, number of months worked and usual weekly hours (including overtime): on the basis of this information, both hourly and monthly wages could be retrieved. Regional unemployment rates and other regional labour market indicators are derived from the Labour Force Survey, as they are periodically published by the National Statistics Office (Istat).

For Germany, our main data sources are the waves 1996-2003 of the German microcensus (MC). The microcensus is the official representative statistic of the population and the labour market, involving 1 percent of all households in Germany every year. The total number of households participating in the microcensus is about 370,000 (encompassing 820,000 persons), including about 70,000 households (about 160,000 persons) in the new Länder and the eastern part of Berlin. All households have the same probability of selection for the microcensus.

Every year, a quarter of all households included in the sample are replaced. This means that every household stays in the sample for four years. Household numbers are not included in the Scientific Use File. Hence, the German microcensus and our Italian data cannot be used as a panel at the individual level. This is no problem, however, because we use panel estimations on the basis of regional averages.

The annual standard programme of the microcensus includes characteristics on 
persons (age, sex, citizenship, etc.), the family and household context. In addition, we know the main and the secondary place of residence, whether the individual is employed, on job search, unemployed or out of the labour force. There is information on the number of children at pre-primary age, pupils, students in the household and information on individual general and vocational level of qualification and on the level of the individual and household net incomes. The microcensus is the data set which is most adequate for our research purpose because it combines two advantages: a huge sample size and a large number of covariates at the individual level. The following variables from the microcensus are used in our estimations: net income ${ }^{16}$, working time, qualification, job tenure, federal state (Land) the individual lives in, and personal characteristics (age and gender). Besides the microcensus, we use the INKAR (an acronym for indicators and maps of regional development) database and data provided by the German Federal Statistical Office. From the INKAR database, the variable "average yearly unemployment rate at state-level" is used.

For both Italy and Germany, we derive hourly income by dividing net income by working time ${ }^{17}$. We selected this wage measure with respect to other alternatives (such as annual or monthly earnings) because a measure of wages influenced by the number of days worked, can lead to biased estimates of the wage curve (BLANCHARD and KATZ, 1997; GARCIA and MONTUENGA, 2003; KENNEDY and BORLAND, $2000)^{18}$

We construct the variable "years of education" by using the information on the highest degree of schooling and professional education, taking the standard lengths of all primary, secondary, and tertiary qualifications and add them up accordingly for each person. The variable "labour market experience" is constructed by subtracting the years 
of education plus six from age. Hence, we actually use a proxy for potential labour market experience ${ }^{19}$.

\section{Results}

Table 1 presents some estimates of the wage curve for Italy (first panel) and Germany (second panel) using different estimation techniques. The dependent variable used to obtain the estimates reported in Table 1 is derived from area fixed effects (i.e. conditional mean hourly earnings at the regional level), computed in a first stage regression in which, for each year, controls for individual characteristics were also included $^{20}$.

In models 1 and 2 we report estimates obtained by fitting the traditional specification of the wage curve - as described in equation [4] - while in the remaining models we report estimates of the ECM specification of equation [5] with the dependent variable in first differences and a lagged term on the right-hand-side ${ }^{21}$. In models 1 and 3 we assess the extent of the potential bias due to the omission of regional fixed effects on the estimate of the elasticity of regional unemployment; the latter are included in the remaining models. In model 6 , the change in regional unemployment is added ${ }^{22}$. It is worth noting that in model 4 the current unemployment rate is used instead of the lagged one. As a first robustness check, in column 7 we report estimates of model 6 on the basis of cell means instead of using the 2-stage procedure. Finally, given the potential simultaneity between wages and regional unemployment, in the last model we use an Instrumental Variables (IV) estimator (BALTAGI and BLIEN, 1998; GARCIA and MONTUENGA, 2003). 
(Table 1 around here)

In general, results show no evidence for a statistically significant negative relationship linking unemployment rates to wages at a regional level in Italy. Similar results were found by LUCIFORA and ORIGO (1999) using alternative data-sets for the 1980s and the first half of the 1990s. Estimates based on cell means are coherent with those obtained by the two-stage procedure (compare columns 6 and 7).

Only those specifications without regional fixed effects have a spurious negative correlation. This points out the importance of including regional fixed effects to get the appropriate estimate of the wage curve. It is interesting to compare these results with those obtained for other countries (particularly the US), showing the existence of a negative relation between wages and local unemployment only when regional fixed effects are included (thus supporting the existence of a wage curve), while a positive and statistically significant relation is found otherwise. The latter has been interpreted as a piece of evidence for the Harris-Todaro compensating differentials theory (BLANCHFLOWER and OSWALD, 2005). This does not apply to Italy (and to some extent to Germany), given that the relation is negative and statistically significant (and hence in contrast with the compensating differentials theory) when fixed effects are not included. Instead, these results clearly suggest that in Italy and Germany labour markets are segmented between high unemployment-low wage areas (in depressed regions) and low unemployment-high wage areas (in booming regions), while wages are generally insensitive to local unemployment shocks (contrary to what happens in the US but similar to the experience in the Nordic countries that are characterised by centralised bargaining, ALBAEK et al., 2000). 
With respect to previous evidence pointing out the existence of a wage curve in Italy (BLANCHFLOWER and OSWALD, 1994a; CANZIANI, 1997; MONTUENGA et al., 2003, 2006), we use a longer time span and we pay greater attention to the inclusion of regional fixed effects (thus using a within estimator) in the second stage ${ }^{23}$. Furthermore, we control for both workers' heterogeneity and the possible endogeneity of unemployment.

Using a different data set (administrative micro-data from the National Social Security Office), a different definition of wages (weekly gross wages) and focusing on a different time period (1985-1999), also DEVICIENTI et al. (2008) have recently found some evidence of a wage curve in Italy, but the estimated elasticity is still rather small (less than 0.03 in absolute value).

Regarding the dynamics of real wages, in the case of Italy we found a negative relationship between the current wage level and its lagged term (given that the estimated $\alpha$ is usually greater than one in absolute terms $)^{24}$. This is probably due to the protracted contraction experienced by real wages in Italy in the first half of the Nineties: since the 1992-1993 recession and the 1993 income policy that reshaped the system of collective bargaining (see section 3), real wages have been declining. The institutional reforms implemented at the beginning of the Nineties have influenced also downward real wage rigidity, which has been progressively declining in Italy over the period considered (DEVICIENTI et al., 2007). Real wages started to increase again, although at a low pace, only in the second half of the 1990s and only at the end of the decade they were again close to the pre-recession levels. In subsequent years, while most European countries experienced a long phase of real wage growth, in Italy they remained roughly stagnant (CONTINI et al., 2007). 
For Germany results are quite sensitive to our model specification: while no evidence for a wage curve seems to emerge from the traditional specification in levels, ECM reparameterisation points out the existence of a (weakly) significant negative effect of regional unemployment on wages, even if the size of the effect is much smaller than what the mainstream empirical evidence predicts (in absolute value, the short run elasticity is around 0.06). ${ }^{25}$ If we compare the results of model (8) with those of models (6) or (7) we see that exogenising the contemporary unemployment rate using the lagged unemployment rate as instruments does not change the results ${ }^{26}$. One possible explanation is that the changes in regional unemployment from year to year might be so small that we do not gain a lot of additional information by this procedure.

Focusing on the dynamics of wages, it shows that the coefficient $\alpha$ on the lagged dependent variable is generally significantly different from both 0 and 1 , suggesting that there might be substantial inertia in the adjustment process of wages.

In a next step we empirically estimate if our theoretical hypotheses on different wage curves for certain sub-groups on the labour market are supported. We also take into account that there might be spatial heterogeneity in the wage curves between regions (BÜTTNER, 1999; LONGHI et al., 2006; ELHORST et al., 2007) ${ }^{27}$ and therefore split our sample between North and South Italy as well as East and West Germany. Table 2 presents the main results for different sub-groups of our samples, paying specific attention to the role of gender and education ${ }^{28}$. Even after disaggregating the sample, we were unable to detect any statistically significant relationship between wages and regional unemployment in Italy for the sub-groups considered. Only the low educated in Italy have a positive and slightly significant correlation. 
In Germany, the situation is quite different. Here mainly females, people in East Germany and low educated employees exhibit a significantly negative wage curve. These results contradict the hypothesis that wages of higher qualified employees react stronger to changes in unemployment, but they are in accordance with the results by BALTAGI and BLIEN (1998) for West Germany and BALTAGI et al. (2000) for East Germany $^{29}$ and a series of papers for other countries (JOHANSEN, 1999 for Norway, KENNEDY and BORLAND, 2000 for Australia, MORRISON et al., 2006 for New Zealand, or GARCIA and MONTUENGA, 2003 for Spain).

With respect to the differences between males and females the results in the literature are mixed (compare JANSSENS and KONINGS, 1998). It is especially stunning that in South Italy the correlation is positive (albeit insignificant) while it is significantly negative for males and females in East Germany. We interpret these results as follows: in South Italy, increases in the (regional) unemployment rate - whilst having a negligible effect on wage levels - significantly increase the flow of discouraged workers, mainly of the low paid ones, out of the (formal) labour market. This also supports our hypothesis that the wage curve is weaker in South Italy than in North Italy due to the black labour market. In East Germany, labour attachment is traditionally high, however, and most people still want to participate even when their chances to find a job decrease. This leads to a strong pressure on wages when unemployment rises.

(Tables $2 \mathrm{a}$ and $2 \mathrm{~b}$ around here)

We also tested whether the reaction of wages to regional unemployment varies along the wage distribution. In Table 3 we present estimates of the wage curve based on first- 
step quantile regressions in correspondence with the relevant deciles of the wage distribution in both Italy and Germany ${ }^{30}$. Reported estimates refer to the usual wage curve specification, both without and with regional fixed effects (model 1 and 2 in Table 1), and to the ECM re-parameterisation (model 6 in Table 1). Results for both Italy and Germany show some evidence in favour of a stronger wage curve relationship for the middle part of the wage distribution, but also in this case our conclusions depend on the model specification adopted. In the case of Italy, with the ECM specification we obtain a significant negative relation between regional unemployment and wages at the median and at the $6^{\text {th }}$ decile, while the effect of unemployment is significantly positive for the lowest decile. This pattern is mainly driven by the males and the North (compare Tables in Appendix)

For Germany the relation between regional unemployment and wages is significant for the fourth quantile and higher. This is also found by BÜTTNER and FITZENBERGER (1998). German males in the middle of the wage distribution do have higher significant correlations while for females also the extreme quartiles exhibit a sizeable negative correlation. While in West Germany comparably to Italy the wage curve is only measurable at the $5^{\text {th }}$ and $6^{\text {th }}$ quartile, there is a negative and significant effect for almost all quartiles in the East. We therefore find weak support for the hypothesis that wages on the mid-upper part of the wage distribution react more to unemployment.

(Tables 3 around here) 


\section{Concluding Remarks}

This study provides a theoretical framework and an empirical test of the elasticity of wages to regional unemployment by employee groups and regions in Italy and Germany, taking into account the effect of country-specific institutions. Large gaps in unemployment rates among different areas (mainly between Northern and Southern regions in Italy and East and West in Germany) are associated with persistent geographical wage differentials. This evidence seems to contradict both economic theory and empirical evidence predicting a negative relationship linking wage levels to regional unemployment rates.

In this paper we argue that the effect of regional unemployment on wages depends on both individual characteristics (including participation decisions) and the specific mix of labour market institutions prevailing in a certain country. Differences in the latter may explain why, for the same group in the population, wage elasticity to regional labour market conditions may differ substantially by country.

In this sense, the comparison between Italy and Germany is quite interesting, since the two countries are characterised by a similar institutional macro-environment (centralised wage bargaining, strong central unions, strict employment protection legislation), but by quite different patterns in regional labour market attachment, especially for females in high unemployment regions. While female participation in East Germany is higher than in the West and quite independent from changes in regional unemployment rates, female participation in the South of Italy is very low and highly reactive to regional labour market conditions.

The main results of our empirical analysis confirm the role of females in high unemployment regions, coupled with regional labour market institutions, in influencing 
regional wage flexibility. In the case of Germany, wage elasticity is in fact higher for females in Eastern regions, while in Italy the relation between wages and regional unemployment is generally much weaker and not statistically significant. In both countries, the reaction of wages to regional unemployment varies significantly along the wage distribution, being more sensitive around the median quantiles.

In the case of Italy, women in the South seem to act as a "buffer" over the business cycle, thus keeping unemployment relatively stable and reducing the effect of the latter on wages. On the contrary, women in East Germany are very attached to the labour market (also due to the availability of good child care and other regional public services) and changes in regional unemployment there have strong (negative) effects on wages.

Results for Italy may also be explained considering the weight of the underground economy, mainly in the South: if the latter is taken into account, then these findings might simply indicate that adjustment does not occur in the regular sector of the economy, but rather outside of it. This interpretation seems particularly suggestive, though the lack of detailed information on the informal sector makes it only tentative.

Furthermore in East Germany, mainly for employees in the middle of the wage distribution, it might not be financially interesting to react to unemployment changes by migrating to other parts of the country or leaving the labour force. Therefore, wages react to changes in unemployment for these groups giving rise to high regional wage flexibility.

Overall, our results highlight that individual and institutional heterogeneity are crucial factors in determining wage elasticity to regional labour market conditions, thus calling for further research by groups for different countries. 
References

ALBAEK K., ASPLUND R., BLOMSKOG S., BARTH E., GUDMUNDSSON B., KARLSSON V. and MADSEN E. (2000) Dimensions of the wage-

AMMERMÜLLER A., KUCKULENZ A. and ZWICK T. (2008) Aggregate unemployment decreases individual returns to education, Economics of Education Review forthcoming;

ANSELIN L. (1988) Spatial Econometrics: Methods and Models, Kluwer Academic Publishers: Dordrecht;

ATTANASIO O. and SCHIOPPA F. (1992) Regional Inequalities, Migration and Mismatch in Italy, 1960-1986, in Padoa Schioppa F. (Ed) The Economics of Mismatch, CEPR, London, 237-320;

BADDELEY M., MARTIN R. and TYLER P. (1998) European regional Unemployment Disparities: Convergence or Persistence?, European Urban and Regional Studies 5 (3), 195-215;

BALTAGI B. and BLIEN U. (1998) The German Wage Curve - Evidence from the IAB Employment Sample, Economics Letters 61, 135-142;

BALTAGI B., BLIEN U. and WOLF K. (2000) The East German wage curve 19931998, Economics Letters 69, 25-31;

BANDE R., FERNÁNDEZ M. and MONTUENGA V. (2007) Regional Disparities in the Unemployment Rate: The Role of the Wage-setting Mechanism in Spain, 1987-92, Regional Studies 41 (2), 235-251; 
BELL B., NICKELL S. and QUINTINI G. (2002) Wage Equations, Wage Curves and all That, Labour Economics 9 (3), 341-360;

BLACK A. and FITZROY F. (2000) Earnings Curves and Wage Curves, Scottish Journal of Political Economy 47, 471-486;

BLANCHARD O. and KATZ L. (1997) What We Know and Do Not Know about the Natural Rate of Unemployment, Journal of Economic Perspectives 11 (1), 5172 ;

BLANCHARD O. and KATZ L. (1999) Wage Dynamics: Reconciling Theory and Evidence, American Economic Review 89 (2) Papers and Proceedings, 69-74;

BLANCHFLOWER D. and OSWALD A. (1990) The Wage Curve, Scandinavian Journal of Economics 92 (2), 215-235;

BLANCHFLOWER D. and OSWALD A. (1994a) The Wage Curve. MIT Press, Cambridge;

BLANCHFLOWER D. and OSWALD A. (1994b) International Wage Curves, in FREEMAN R. and KATZ L. (Eds) Differences and Changes in Wage Structures. University of Chigaco Press, Chicago, 145-174;

BLANCHFLOWER D. and OSWALD A. (2005) The Wage Curve Reloaded, NBER Working Paper 11338, Cambridge, MA;

BODO G. and SESTITO P. (1994) Squilibri territoriali nel mercato del lavoro e inflazione, in DELL'ARINGA C. (Ed) Caratteri strutturali dell'inflazione italiana. Il Mulino, Bologna;

BRUNELLO G., LUPI C. and ORDINE P. (2001) Widening differences in Italian Regional Unemployment, Labour Economics 8, 103-129; 
BÜTTNER T. (1999) The Effect of Unemployment, Aggregate Wages, and Spatial Contiguity on Local Wages: An Investigation with German District Level Data, Papers in Regional Science 78, 47-67;

BÜTTNER T. and FITZENBERGER B. (1998) Central Wage Bargaining and Local Wage Flexibility: Evidence from the Entire Wage Distribution, $Z E W$ Discussion Paper No. 98-39, Mannheim;

CANZIANI P. (1997) The Wage Curve in Italy and Spain: Are European Wages Flexible?, Discussion Paper 375, Centre for Economic Performance, London School of Economics;

CARD D. (1995) The Wage Curve: A Review, Journal of Economic Literature 33 (2), 758-799;

CASADIO P., LAMELAS M. and RODANO G. (2005) Cambiamento istituzionale, salari e flessibilità: l'esperienza della concertazione in Italia, Rivista Internazionale di Scienze Sociali 2, 185-214;

CASAVOLA P., GAVOSTO A. and SESTITO P. (1995) Salari e mercato del lavoro locale, Lavoro e Relazioni Industriali: Rivista di Economia Applicata 4, 39-83;

CONTINI B., LEOMBRUNI R., PACELLI L. and VILLOSIO C. (2007) Wage Mobility and Dynamics in Italy in the 90s, NBER Working Paper 13029, Cambridge MA;

DELL'ARINGA C., LUCIFORA C. and ORIGO F. (2007) Public Sector Pay and Regional Competitiveness: a First Look at Regional Private-Public Wage Differentials in Italy, The Manchester School 75 (4), 445-478; 
DEVEREUX P. (2004) Cyclical Quality Adjustment in the Labor Market, Southern Economic Journal 70 (3), 600-615;

DEVICIENTI F., MAIDA A. and PACELLI L. (2008) The Resurrection of the Italian Wage Curve, Economic Letters 98 (3), 335-341;

DEVICIENTI F., MAIDA A. and SESTITO P. (2007) Downward Wage Rigidity in Italy: Micro-Based Measures and Implications, Economic Journal 117, F530F552;

ELHORST J., BLIEN U. and WOLF K. (2007) New Evidence on the Wage Curve: A Spatial Panel Approach, International Regional Science Review 30 (2), 173191;

FAGGIO G. and NICKELL S. (2005) The responsiveness of wages to labour market conditions in the UK, Labour Economics 12 (5), 685-696;

FAINI R. (1995) Stesso lavoro, diverso salario? Flessibilità, gabbie salariali e ruolo del sindacato nel mezzogiorno, in AA.VV., Le nuove frontiere della politica economica, Il Sole 24 Ore: Milan;

FAINI R., GALLI G. and ROSSI F. (1996) Mobilità e Disoccupazione in Italia: un'Analisi dell'Offerta di Lavoro, in GALLI G. (Ed) La Mobilità della Società Italiana. SIPI editore, Rome, 253-296;

FAINI R., GALLI G. and ROSSI F. (1997) An Empirical Puzzle: Falling Migration and Growing Unemployment Differentials Among Italian Regions, European Economic Review 41, 571-579;

GARCIA I. and MONTUENGA V. (2003) The Spanish Wage Curve: 1994-1996, Regional Studies 37 (9), 929-945; 
HAMILTON J. (1994) Time Series Analysis. Princeton University Press, Princeton;

HARRIS J. and TODARO M. (1970) Migration, Unemployment, and Development: A Two-Sector Analysis, American Economic Review 60, 126-142;

HART R. (2003) Overtime Working, the Phillips Curve and the Wage Curve: British Engineering 1926-66, The Manchester School 71 (2), 97-112;

JANSSENS S. and KONINGS J. (1998) One more wage curve: the case of Belgium, Economics Letters 60(2), 223-227;

JOHANSEN K. (1999) Wage Flexibility for Skilled and Unskilled Workers: New Evidence on the Norwegian Wage Curve, Labour 12 (2), 413-432;

KENNEDY S. and BORLAND J. (2000) A Wage Curve for Australia?, Oxford Economic Papers 52, 774-803;

KILLINGSWORTH M. (1983) Labor Supply, Cambridge University Press, New York;

LONGHI S., NIJKAMP P. and POOT J. (2006) Spatial Heterogeneity and the Wage Curve Revisited, Journal of Regional Science 46 (4), 707-731;

LAYARD R., NICKELL S. and JACKMAN R. (1991) Unemployment: Macroeconomic performance and the labour market. Oxford University Press, Oxford;

LUCIFORA C. (2003) Economia sommersa e lavoro nero. Il Mulino, Bologna;

LUCIFORA C. and ORIGO F. (1999) Alla ricerca della flessibilità: un'analisi della curva dei salari in Italia, Rivista Italiana degli Economisti 1, 3-35;

MAIDA A., DEVICIENTI F. and PACELLI L. (2005) Revisiting the Wage Curve in Italy, Working Paper Series 02/2005, Department of Economics, Università di Torino, Turin; 
MINCER J. (1991) Education and Unemployment, NBER Working Paper 3838, Cambridge MA;

MONTUENGA V., FERNANDEZ M. and GARCIA L. (2003) Wage Flexibility: Evidence from Five EU Countries Based on the Wage Curve, Economic Letters 78, 169-74;

MONTUENGA V., FERNANDEZ M. and GARCIA L. (2006) Regional Wage Flexibility: The Wage Curve in Five European Countries, in CAROLEO F. and DESTEFANIS S. (Eds) Regions, Europe and the Labour Market. Recent Problems and Developments. Physica Verlag, Heidelberg, 245-265;

MONTUENGA V. and RAMOS J. (2005), Reconciling the Wage Curve and the Phillips Curve, Journal of Economic Surveys 19 (5), 735-765;

MORRISON P., PAPPS K. and POOT J. (2006) Employment, Labour Turnover and the Accessibility of Local Labour Markets, Labour Economics 13 (5), 639-663;

MOULTON B. (1986) Random Group Effects and the Precision of Regression Estimates, Journal of Econometrics 32 (3), 385-397;

MOULTON B. (1990) An Illustration of a Pitfall in Estimating the Effects of Aggregate Variables on Micro Units, Review of Economics and Statistics 72 (2), 334-338;

NIJKAMP P. and POOT J. (2005) The Last Word in the Wage Curve?, Journal of Economic Surveys 19 (3), 421-450;

OECD (2000) OECD Employment Outlook, Chapter 2. OECD, Paris;

OURS J. VAN and RIDDER G. (1995) Job Matching and Job Competition: Are Lower Educated Workers at the Back of Job Queues?, European Economic Review 39, 1717-1731; 
REDER M. (1955) The Theory of Occupational Wage Differentials, American Economic Review 45 (5), 833-852;

SINN G. and SINN H-W. (1991) Kaltstart. Mohr (Siebeck), Tübingen. 
Table 1: Estimates of the wage curve, non agricultural employees in private sector, hourly wages

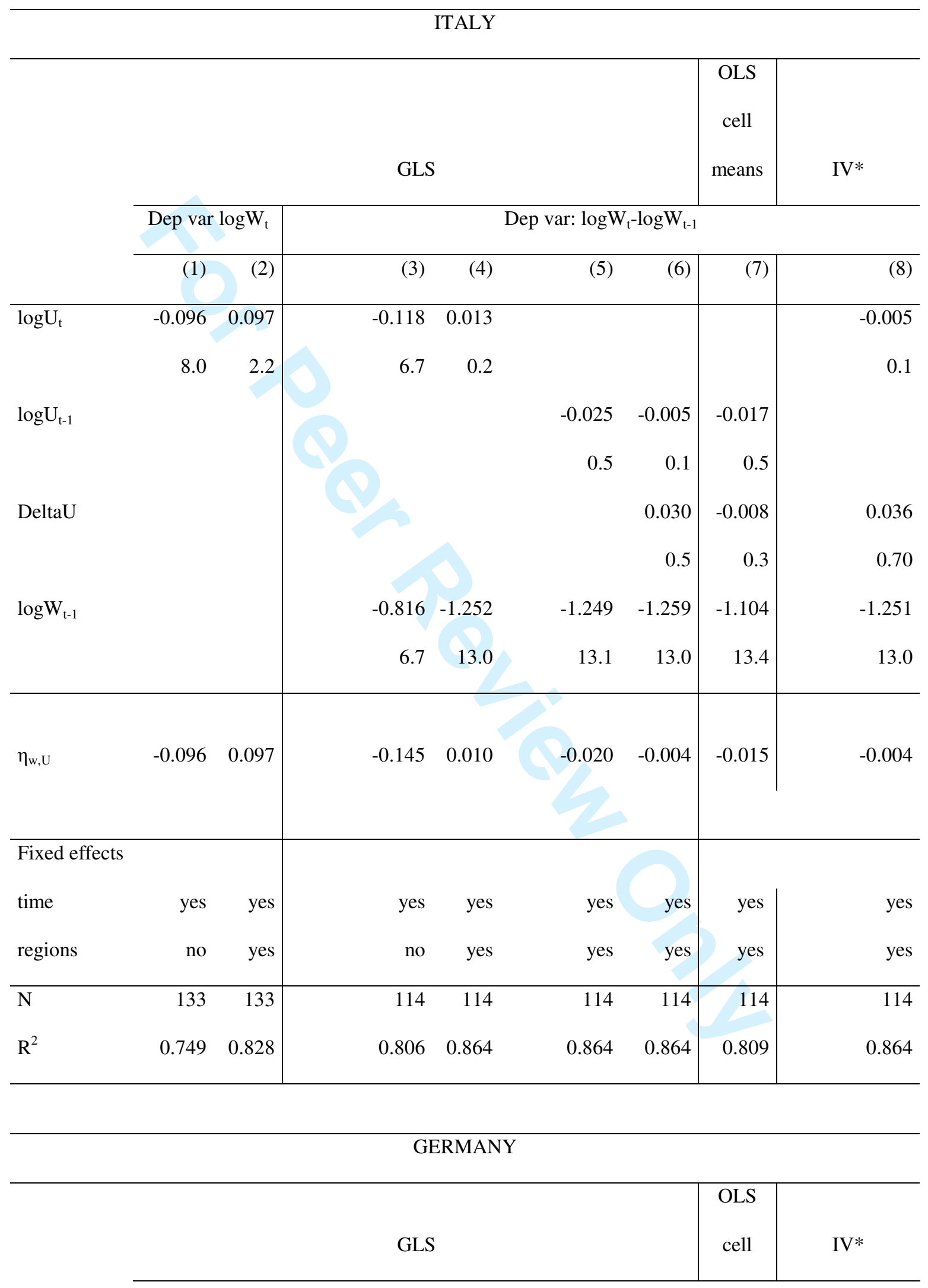


Notes: periods for Italy, 1991-2004; for Germany 1996-2003, absolute t statistics based on robust s.e. are reported below each coefficient. Dependent variable (columns 1-6 and 8): regional fixed effects from a set of first step OLS regressions with individual micro-data (for each year, wage equations with controls for region, gender, years of education, experience, experience squared, tenure and tenure squared). In Column 7, the dependent variable is the difference between means of hourly wages by region and year. Controls are the same as in the other columns, but they are means by region and year. *Lags of unemployment $\left(\mathrm{U}_{\mathrm{t}-1}\right.$ and $\left.\mathrm{U}_{\mathrm{t}-2}\right)$ were used as instruments for $\mathrm{U}_{\mathrm{t}}$. 
Table 2a: Estimates of the wage curve by groups: gender, education and region

\begin{tabular}{|c|c|c|c|c|c|c|c|}
\hline \multicolumn{8}{|c|}{ ITALY } \\
\hline & \multicolumn{7}{|c|}{ Dep var: $\log \mathrm{W}_{\mathrm{t}}-\log \mathrm{W}_{\mathrm{t}-1}$} \\
\hline & Males & Females & Low edu & Mid edu & High edu & North & South \\
\hline \multirow[t]{2}{*}{$\log U_{t-1}$} & -0.009 & 0.034 & 0.126 & -0.089 & -0.075 & -0.028 & 0.190 \\
\hline & $(0.2)$ & $(0.2)$ & $(1.7)$ & $(0.7)$ & $(0.4)$ & $(0.5)$ & $(1.0)$ \\
\hline \multirow[t]{2}{*}{ DeltaU } & 0.025 & 0.197 & 0.137 & -0.141 & 0.040 & -0.031 & 0.181 \\
\hline & $(0.4)$ & (1.3) & $(1.8)$ & (1.2) & $(0.2)$ & $(0.6)$ & $(1.1)$ \\
\hline \multirow[t]{2}{*}{$\log \mathrm{W}_{\mathrm{t}-1}$} & -1.182 & -1.118 & -1.216 & -1.045 & -1.015 & -1.159 & -1.312 \\
\hline & (11.9) & (9.4) & $(12.8)$ & $(9.5)$ & (8.9) & $(9.0)$ & $(8.4)$ \\
\hline \multicolumn{8}{|c|}{ Fixed effects } \\
\hline time & yes & yes & yes & yes & yes & yes & yes \\
\hline regions & yes & yes & yes & yes & yes & yes & yes \\
\hline $\mathrm{N}$ & 114 & 114 & 114 & 114 & 114 & 66 & 48 \\
\hline $\mathrm{R}^{2}$ & 0.916 & 0.602 & 0.854 & 0.414 & 0.522 & 0.913 & 0.946 \\
\hline
\end{tabular}

\section{GERMANY}

\begin{tabular}{|c|c|c|c|c|c|c|c|}
\hline & & & Dep & $\mathrm{r}: \log \mathrm{W}_{\mathrm{t}}-1$ & $\mathrm{gW}_{\mathrm{t}-1}$ & & \\
\hline & Males & Females & Low edu & Mid edu & High edu & West & East \\
\hline $\log U_{t-1}$ & -0.050 & -0.103 & -0.064 & -0.047 & -0.006 & 0.006 & -0.309 \\
\hline & (1.4) & (2.3) & (1.7) & $(0.8)$ & $(0.1)$ & $(0.1)$ & (1.9) \\
\hline DeltaU & -0.073 & -0.057 & -0.022 & -0.149 & -0.077 & 0.005 & -0.170 \\
\hline & (1.5) & $(0.9)$ & $(0.4)$ & (1.8) & (1.0) & $(0.1)$ & (1.4) \\
\hline $\log W_{t-1}$ & -0.229 & -0.303 & -0.203 & -0.397 & -0.771 & -0.248 & -0.256 \\
\hline
\end{tabular}




\begin{tabular}{lcc|ccc|cc} 
& $(2.5)$ & $(3.0)$ & $(2.2)$ & $(3.8)$ & $(6.5)$ & $(1.7)$ & $(2.4)$ \\
\multicolumn{2}{l|}{ Fixed effects } & & & & & & \\
time & yes & yes & yes & yes & yes & yes & yes \\
regions & yes & yes & yes & yes & yes & yes & yes \\
\hline $\mathrm{N}$ & 112 & 112 & 112 & 112 & 112 & 70 & 42 \\
$\mathrm{R}^{2}$ & 0.95 & 0.846 & 0.887 & 0.750 & 0.996 & 0.940 & 0.933 \\
\hline \hline
\end{tabular}

Notes: see table 1. 
Table 2b: Estimates of the wage curve by groups: gender by region

\begin{tabular}{|c|c|c|c|c|}
\hline \multicolumn{5}{|c|}{ ITALY } \\
\hline & \multicolumn{4}{|c|}{ Dep var: $\log \mathrm{W}_{\mathrm{t}}-\log \mathrm{W}_{\mathrm{t}-1}$} \\
\hline & \multicolumn{2}{|c|}{ North } & \multicolumn{2}{|c|}{ South } \\
\hline & Males & Females & Males & Females \\
\hline \multirow[t]{2}{*}{$\log U_{t-1}$} & -0.047 & -0.018 & 0.131 & 0.258 \\
\hline & $(0.9)$ & $(0.2)$ & $(0.6)$ & $(0.7)$ \\
\hline \multirow[t]{2}{*}{ DeltaU } & -0.037 & -0.048 & 0.081 & 0.656 \\
\hline & $(0.7)$ & $(0.5)$ & $(0.4)$ & $(2.0)$ \\
\hline \multirow[t]{2}{*}{$\log \mathrm{W}_{\mathrm{t}-1}$} & -0.954 & -1.177 & -1.459 & -0.968 \\
\hline & (8.3) & (7.6) & (9.4) & (5.3) \\
\hline \multicolumn{5}{|c|}{ Fixed effects } \\
\hline time & yes & yes & yes & yes \\
\hline regions & yes & yes & yes & yes \\
\hline $\mathrm{N}$ & 66 & 66 & 48 & 48 \\
\hline $\mathrm{R}^{2}$ & 0.868 & 0.770 & 0.927 & 0.917 \\
\hline
\end{tabular}

GERMANY

Dep var: $\log \mathrm{W}_{\mathrm{t}}-\log \mathrm{W}_{\mathrm{t}-1}$

\begin{tabular}{lcc|cc} 
& \multicolumn{2}{c|}{ West } & \multicolumn{2}{c}{ East } \\
\hline & Males & Females & Males & Females \\
\hline $\log \mathrm{U}_{\mathrm{t}-1}$ & -0.068 & 0.081 & -0.412 & -0.378 \\
& $(0.8)$ & $(0.7)$ & $(2.2)$ & $(1.7)$ \\
DeltaU & -0.033 & -0.007 & -0.282 & -0.137 \\
& & & &
\end{tabular}




\begin{tabular}{lcccc} 
& $(0.3)$ & $(0.1)$ & $(2.0)$ & $(0.9)$ \\
$\log \mathrm{W}_{\mathrm{t}-1}$ & -0.280 & -0.294 & -0.295 & -0.484 \\
& $(1.8)$ & $(2.1)$ & $(2.1)$ & $(3.0)$ \\
Fixed effects & & & & \\
time & yes & yes & yes & yes \\
regions & yes & yes & yes \\
\hline $\mathrm{N}$ & 70 & 70 & 42 & 42 \\
$\mathrm{R}^{2}$ & 0.948 & 0.843 & 0.943 & 0.894 \\
\hline
\end{tabular}

Notes: see table 1. 
Table 3: Estimates of the wage curve along the wage distribution

ITALY

\begin{tabular}{|c|c|c|c|c|c|c|c|c|c|}
\hline \multirow[b]{2}{*}{ Deciles: } & \multicolumn{9}{|c|}{ Dep var: $\log W_{t}$} \\
\hline & 0.1 & 0.2 & 0.3 & 0.4 & 0.5 & 0.6 & 0.7 & 0.8 & 0.9 \\
\hline \multicolumn{10}{|c|}{ Model without regional fixed effects } \\
\hline \multirow[t]{2}{*}{$\log U_{t}$} & -0.216 & -0.174 & -0.137 & -0.117 & -0.097 & -0.078 & -0.065 & -0.050 & -0.034 \\
\hline & $(11.0)$ & $(12.5)$ & $(11.1)$ & $(10.5)$ & $(9.2)$ & (7.8) & $(5.9)$ & (4.4) & $(2.0)$ \\
\hline \multicolumn{10}{|c|}{ Model with fixed regional effects } \\
\hline \multirow[t]{2}{*}{$\log \mathrm{U}_{\mathrm{t}}$} & 0.196 & 0.078 & 0.045 & 0.036 & 0.014 & 0.014 & 0.037 & 0.027 & 0.012 \\
\hline & $(2.7)$ & $(1.5)$ & $(1.0)$ & $(0.8)$ & $(0.4)$ & $(0.4)$ & $(0.9)$ & $(0.7)$ & $(0.2)$ \\
\hline
\end{tabular}

\section{Error Correction Model}

\begin{tabular}{|c|c|c|c|c|c|c|c|c|c|}
\hline \multirow[t]{2}{*}{$\log U_{t-1}$} & 0.241 & 0.055 & -0.017 & -0.050 & -0.090 & -0.093 & -0.045 & -0.059 & -0.041 \\
\hline & (2.3) & $(0.8)$ & $(0.3)$ & $(0.9)$ & (1.8) & $(2.1)$ & $(0.8)$ & $(0.9)$ & $(0.4)$ \\
\hline \multirow[t]{2}{*}{ DeltaU } & 0.223 & 0.050 & 0.000 & -0.007 & -0.030 & -0.045 & -0.023 & -0.123 & 0.009 \\
\hline & (2.3) & $(0.8)$ & $(0.0)$ & $(0.1)$ & $(0.6)$ & $(1.0)$ & $(0.4)$ & $(0.2)$ & $(0.1)$ \\
\hline \multirow[t]{2}{*}{$\log \mathrm{W}_{\mathrm{t}-1}$} & -1.260 & -1.151 & -1.175 & -1.098 & -1.129 & -1.125 & -1.127 & -1.050 & -1.337 \\
\hline & (13.9) & (13.2) & $(13.4)$ & (11.8) & (11.4) & (11.9) & (11.6) & (9.1) & (9.9) \\
\hline$\eta_{\mathrm{w}, \mathrm{U}}$ & 0.191 & 0.048 & -0.014 & -0.046 & -0.080 & -0.083 & -0.040 & -0.056 & -0.031 \\
\hline \multicolumn{10}{|c|}{ GERMANY } \\
\hline & \multicolumn{9}{|c|}{ Dep var: $\log \mathrm{W}_{\mathrm{t}}$} \\
\hline Deciles: & 0.1 & 0.2 & 0.3 & 0.4 & 0.5 & 0.6 & 0.7 & 0.8 & 0.9 \\
\hline
\end{tabular}

Model without regional fixed effects 


$\begin{array}{rccccccccc}\log \mathrm{U}_{\mathrm{t}} & -0.291 & -0.305 & -0.316 & -0.321 & -0.334 & -0.339 & -0.348 & -0.360 & -0.408 \\ & (16.1) & (16.4) & (16.3) & (16.8) & (16.7) & (16.7) & (17.0) & (17.0) & (15.5)\end{array}$

Model with fixed regional effects

$\begin{array}{rccccccccc}\log \mathrm{U}_{\mathrm{t}} & 0.021 & 0.006 & 0.028 & -0.051 & -0.030 & -0.030 & -0.035 & -0.049 & -0.115 \\ & (0.9) & (0.4) & (1.5) & (4.3) & (2.2) & (1.9) & (1.9) & (2.0) & (2.1)\end{array}$

\section{Error Correction Model}

\begin{tabular}{|c|c|c|c|c|c|c|c|c|c|}
\hline \multirow[t]{2}{*}{$\log U_{t-1}$} & -0.030 & -0.014 & -0.019 & -0.056 & -0.030 & -0.047 & -0.045 & -0.069 & -0.099 \\
\hline & (1.4) & $(0.8)$ & (1.3) & $(4.2)$ & $(2.3)$ & $(4.0)$ & (3.1) & (3.2) & (1.8) \\
\hline \multirow[t]{2}{*}{ DeltaU } & -0.013 & -0.033 & -0.006 & -0.034 & -0.030 & -0.048 & -0.037 & -0.086 & -0.116 \\
\hline & $(0.4)$ & (1.2) & $(0.2)$ & $(2.2)$ & (1.9) & (2.7) & (1.8) & (3.0) & (1.7) \\
\hline \multirow[t]{2}{*}{$\log \mathrm{W}_{\mathrm{t}-1}$} & -0.592 & -0.597 & -0.439 & -0.576 & -0.429 & -0.386 & -0.481 & -0.397 & -0.257 \\
\hline & (5.9) & (5.3) & (3.8) & (6.0) & $(4.5)$ & (5.3) & (5.1) & (4.6) & $(1.2)$ \\
\hline$\eta_{\mathrm{w} . \mathrm{U}}$ & -0.051 & -0.023 & -0.043 & -0.097 & -0.070 & -0.122 & -0.094 & -0.174 & -0.385 \\
\hline
\end{tabular}

Notes: for Italy, 1991-2004; for Germany 1996-2003, absolute t statistics based on robust s.e. are reported below each coefficient, models specification as in Table 1, dependent variable: regional fixed effects from a set of first step quantile regressions with individual micro-data (for each year, wage equations with controls for region, gender, years of education, experience, experience squared, tenure and tenure squared). 


\section{APPENDIX}

2

3

4

5

6

7

8

9

10

11

12

13

14

15

16

17

18

19

20

21

22

23

24

25

26

27

28

29

30

31

32

33

34

35

36

37

38

39

40

41

42

43

44

45

46

47

48

49

50

51

52

53

54

55

56

57

58

59

60 
Table I: Estimates of the wage curve along the wage distribution by gender, ITALY

\begin{tabular}{|c|c|c|c|c|c|c|c|c|c|}
\hline \multicolumn{10}{|c|}{ MALES } \\
\hline \multirow[b]{2}{*}{ Deciles: } & \multicolumn{9}{|c|}{ Dep var: $\log W_{t}$} \\
\hline & 0.1 & 0.2 & 0.3 & 0.4 & 0.5 & 0.6 & 0.7 & 0.8 & 0.9 \\
\hline \multicolumn{10}{|c|}{ Model without regional fixed effects } \\
\hline \multirow[t]{2}{*}{$\log U_{t}$} & -0.202 & -0.158 & -0.137 & -0.103 & -0.087 & -0.067 & -0.043 & -0.055 & -0.034 \\
\hline & (7.5) & (10.9) & $(10.9)$ & (9.6) & (8.6) & (6.6) & $(4.5)$ & (4.7) & (1.8) \\
\hline \multicolumn{10}{|c|}{ Model with fixed regional effects } \\
\hline \multirow[t]{2}{*}{$\log \mathrm{U}_{\mathrm{t}}$} & 0.199 & 0.061 & 0.01 & 0.043 & 0.018 & 0.017 & 0.095 & 0.007 & -0.002 \\
\hline & $(1.8)$ & $(1.1)$ & $(0.2)$ & $(1.0)$ & $(0.5)$ & $(0.4)$ & $(2.3)$ & $(0.2)$ & $(0.1)$ \\
\hline
\end{tabular}

Dep var: $\log \mathrm{W}_{\mathrm{t}}-\log \mathrm{W}_{\mathrm{t}-1}$

\section{Error Correction Model}

$\begin{array}{rccccccccc}\log \mathrm{U}_{\mathrm{t}-1} & 0.299 & -0.008 & -0.073 & -0.053 & -0.087 & -0.116 & -0.040 & -0.090 & -0.038 \\ & (1.8) & (0.1) & (1.1) & (1.0) & (1.7) & (2.2) & (0.7) & (1.3) & (0.4)\end{array}$

$\begin{array}{llllllllll}\text { DeltaU } & 0.272 & 0.008 & -0.068 & -0.037 & -0.061 & -0.070 & -0.033 & -0.055 & -0.052\end{array}$
$(1.7)$
$(0.1)$
(1.1) (0.7)
(1.2)
(1.4) (0.6)
$(0.8) \quad(0.5)$

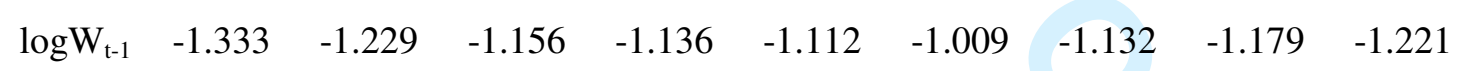

$\begin{array}{lllllllll}(13.3) & (13.1) & (11.9) & (11.5) & (11.4) & (10.0) & (10.9) & (10.3)\end{array}$

\begin{tabular}{llllllllll} 
& $(13.3)$ & $(13.1)$ & $(11.9)$ & $(11.5)$ & $(11.4)$ & $(10.0)$ & $(10.9)$ & $(10.3)$ & $(8.3)$ \\
\cline { 2 - 9 } & & & & & & & & & \\
$\eta_{\mathrm{w}, \mathrm{U}}$ & 0.224 & -0.007 & -0.063 & -0.047 & -0.078 & -0.115 & -0.035 & -0.076 & -0.031
\end{tabular}

FEMALES

\begin{tabular}{llllllllll}
\hline & \multicolumn{10}{c}{ Dep var: $\log \mathrm{W}_{\mathrm{t}}$} \\
Deciles: & 0.1 & 0.2 & 0.3 & 0.4 & 0.5 & 0.6 & 0.7 & 0.8 & 0.9
\end{tabular}

Model without regional fixed effects 


$\begin{array}{rccccccccc}\log \mathrm{U}_{\mathrm{t}} & -0.272 & -0.204 & -0.184 & -0.151 & -0.124 & -0.112 & -0.071 & -0.070 & -0.070 \\ & (7.2) & (6.1) & (7.6) & (6.6) & (5.5) & (5.3) & (3.5) & (3.4) & (2.9)\end{array}$

Model with fixed regional effects

$\begin{array}{llllllllll}\log U_{\mathrm{t}} & 0.293 & 0.186 & 0.098 & 0.051 & 0.038 & -0.002 & 0.017 & -0.002 & 0.003\end{array}$
$(2.0)$
$(1.4) \quad(1.0) \quad(0.6)$
$(0.4)$
$(0.1)$
$(0.2)$
$(0.3) \quad(0.3)$

Error Correction Model

$\begin{array}{rccccccccc}\log \mathrm{U}_{\mathrm{t}-1} & 0.375 & 0.143 & 0.016 & -0.024 & 0.029 & -0.062 & -0.062 & -0.113 & -0.027 \\ & (1.7) & (0.6) & (0.1) & (0.2) & (0.2) & (0.5) & (0.5) & (0.9) & (0.2)\end{array}$

$\begin{array}{llllllllll}\text { DeltaU } & 0.430 & 0.273 & 0.145 & 0.004 & 0.165 & 0.118 & 0.065 & 0.019 & 0.149\end{array}$

$\begin{array}{llllllll}(2.0) & (1.3) \quad(1.0) \quad(0.1) \quad(1.3) \quad(0.9) \quad(0.6) \quad(0.2) \quad(1.2)\end{array}$

$\begin{array}{llllllllll}\log \mathrm{W}_{\mathrm{t}-1} & -0.741 & -1.129 & -1.040 & -1.055 & -1.232 & -1.369 & -1.287 & -1.338 & -1.401\end{array}$

$\begin{array}{llllllll}(6.6) & (9.7) & (11.7) & (10.7) & (12.9) & (13.4) & (12.9) & (11.7)\end{array}$

$\begin{array}{llllllllll}\eta_{\mathrm{w} . \mathrm{U}} & 0.506 & 0.127 & 0.015 & -0.023 & 0.024 & -0.045 & -0.048 & -0.084 & -0.019\end{array}$

Notes: for Italy, 1991-2004, absolute t statistics based on robust s.e. are reported below each coefficient, models specification as in Table 1, dependent variable: regional fixed effects from a set of first step quantile regressions with individual micro-data (for each year, wage equations with controls for region, gender, years of education, experience, experience squared, tenure and tenure squared). 
Table II: Estimates of the wage curve along the wage distribution by gender,

\section{GERMANY}

\section{MALES}

Dep var: $\log \mathrm{W}_{\mathrm{t}}$

\begin{tabular}{|c|c|c|c|c|c|c|c|c|}
\hline Deciles: & 0.1 & 0.2 & 0.3 & 0.4 & 0.5 & 0.6 & 0.7 & 0.8 \\
\hline
\end{tabular}

Model without regional fixed effects

$\begin{array}{llllllllll}\log \mathrm{U}_{\mathrm{t}} & -0.349 & -0.353 & -0.363 & -0.371 & -0.390 & -0.398 & -0.409 & -0.415 & -0.444 \\ & (18.63) & (19.29) & (18.94) & (19.11) & (18.81) & (18.79) & (18.51) & (17.94) & (16.3)\end{array}$

Model with fixed regional effects

$\begin{array}{lcccccccccc}\log U_{\mathrm{t}} & 0.023 & -0.039 & 0.001 & -0.051 & -0.051 & -0.064 & -0.060 & -0.039 & -0.070 \\ & (0.84) & (2.33) & (0.0) & (3.5) & (3.46) & (3.33) & (2.77) & (1.27) & (1.44)\end{array}$

Dep var: $\log \mathrm{W}_{\mathrm{t}}-\log \mathrm{W}_{\mathrm{t}-1}$

\section{Error Correction Model}

$\begin{array}{lcccccccccc}\log \mathrm{U}_{\mathrm{t}-1} & -0.023 & -0.037 & -0.030 & -0.046 & -0.042 & -0.055 & -0.045 & -0.039 & -0.041 \\ & (0.8) & (1.9) & (1.9) & (3.2) & (3.2) & (3.4) & (2.3) & (1.6) & (0.8) \\ \operatorname{DeltaU} & 0.005 & -0.030 & -0.240 & -0.029 & -0.028 & -0.045 & -0.058 & -0.088 & -0.134 \\ & (0.1) & (1.1) & (1.0) & (1.5) & (1.6) & (2.1) & (2.1) & (2.4) & (2.0) \\ \log \mathrm{W}_{\mathrm{t}-1} & -0.655 & -0.563 & -0.435 & -0.512 & -0.422 & -0.468 & -0.551 & -0.419 & -0.292 \\ & (6.9) & (5.3) & (5.2) & (6.9) & (4.9) & (4.9) & (6.2) & (5.2) & (2.2) \\ & & & & & & & & & \\ \eta_{\mathrm{w}, \mathrm{U}} & -0.035 & -0.066 & -0.069 & -0.090 & -0.100 & -0.118 & -0.082 & -0.093 & -0.140\end{array}$

FEMALES

Dep var: $\log \mathrm{W}_{\mathrm{t}}$ 


\begin{tabular}{|c|c|c|c|c|c|c|c|c|c|}
\hline Deciles: & 0.1 & 0.2 & 0.3 & 0.4 & 0.5 & 0.6 & 0.7 & 0.8 & 0.9 \\
\hline \multicolumn{10}{|c|}{ Model without regional fixed effects } \\
\hline \multirow[t]{2}{*}{$\log \mathrm{U}_{\mathrm{t}}$} & -0.157 & -0.203 & -0.210 & -0.222 & -0.227 & -0.234 & -0.249 & -0.276 & -0.360 \\
\hline & (7.1) & $(10.0)$ & (10.9) & (12.1) & (12.3) & $(13.0)$ & (13.6) & (13.9) & (11.3) \\
\hline
\end{tabular}

\begin{tabular}{lllllllllll}
\hline \multicolumn{1}{l}{ Model with fixed regional effects } \\
\\
$\log \mathrm{U}_{\mathrm{t}}$ & -0.049 & 0.068 & -0.035 & -0.037 & 0.006 & -0.041 & -0.041 & -0.073 & -0.219 \\
& $(1.6)$ & $(2.6)$ & $(1.3)$ & $(1.9)$ & $(0.3)$ & $(1.9)$ & $(2.0)$ & $(2.7)$ & $(2.1)$ \\
\hline
\end{tabular}

Error Correction Model

$\begin{array}{rllllllllll}\log \mathrm{U}_{\mathrm{t}-1} & -0.108 & 0.042 & -0.096 & -0.037 & -0.040 & -0.076 & -0.080 & -0.114 & -0.246 \\ & (2.8) & (1.5) & (3.1) & (1.6) & (2.0) & (4.4) & (4.1) & (3.8) & (2.5)\end{array}$

$\begin{array}{llllllllll}\text { DeltaU } & 0.015 & 0.001 & 0.006 & -0.027 & -0.007 & -0.041 & -0.018 & -0.011 & -0.027\end{array}$
$(0.2) \quad(0.0)$
$(0.1) \quad(0.9)$
$(0.2)$
(1.5)
$(0.6)$
(0.3) (0.2)

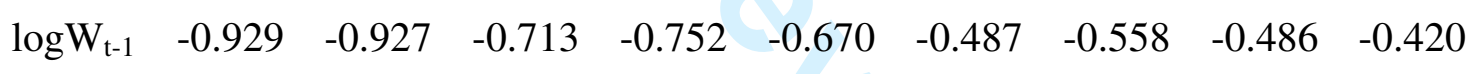

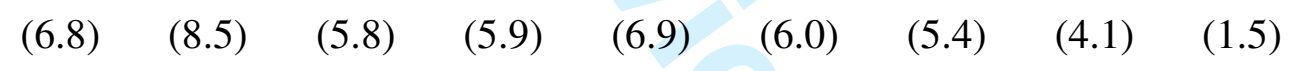

$\begin{array}{llllllllll}\eta_{\mathrm{w} . \mathrm{U}} & -0.116 & 0.045 & -0.135 & -0.049 & -0.060 & -0.156 & -0.143 & -0.235 & -0.586\end{array}$

Notes: for Germany, 1996-2003, absolute t statistics based on robust s.e. are reported below each coefficient, models specification as in Table 1, dependent variable: regional fixed effects from a set of first step quantile regressions with individual micro-data (for each year, wage equations with controls for region, gender, years of education, experience, experience squared, tenure and tenure squared). 
Table III: Estimates of the wage curve along the wage distribution by region, ITALY

\section{NORTH}

Dep var: $\log \mathrm{W}_{\mathrm{t}}$

\begin{tabular}{|c|c|}
\hline Deciles & 0 \\
\hline
\end{tabular}

Model without regional fixed effects

$\begin{array}{rccccccccc}\log \mathrm{U}_{\mathrm{t}} & -0.111 & -0.12 & -0.092 & -0.089 & -0.092 & -0.092 & -0.074 & -0.065 & -0.061 \\ & (4.0) & (4.6) & (4.2) & (4.2) & (4.0) & (3.8) & (2.9) & (2.3) & (1.8)\end{array}$

Model with fixed regional effects

$\begin{array}{llllllllll}\log \mathrm{U}_{\mathrm{t}} & 0.029 & 0.053 & 0.044 & 0.036 & 0.033 & 0.019 & 0.047 & 0.029 & 0.027 \\ & (0.6) & (1.1) & (1.1) & (1.1) & (1.0) & (0.6) & (1.3) & (0.7) & (0.6)\end{array}$

Dep var: $\log \mathrm{W}_{\mathrm{t}}-\log \mathrm{W}_{\mathrm{t}-1}$

\section{Error Correction Model}

$\begin{array}{llllllllll}\log \mathrm{U}_{\mathrm{t}-1} & 0.094 & 0.050 & 0.042 & -0.009 & -0.051 & -0.068 & -0.043 & -0.089 & -0.084\end{array}$
(1.2) (0.6)
$(0.7)$
$(0.2)$
$(0.9) \quad(1.3) \quad(0.6)$
(1.4) (0.3)

$\begin{array}{llllllllll}\text { DeltaU } & -0.027 & 0.019 & 0.0340 & 0.001 & -0.023 & -0.006 & 0.008 & -0.034 & -0.027\end{array}$

$$
\begin{array}{lcccccccccc} 
& (0.4) & (0.3) & (0.6) & (0.1) & (0.4) & (0.1) & (0.1) & (0.6) & (0.3) \\
\log \mathrm{W}_{\mathrm{t}-1} & -1.317 & -1.207 & -1.138 & -1.222 & -1.158 & -1.082 & -0.996 & -0.882 & -1.171 \\
& (10.5) & (8.9) & (8.9) & (8.6) & (8.7) & (8.1) & (6.8) & (6.5) & (6.9) \\
& & & & & & & & & \\
\eta_{\mathrm{w}, \mathrm{U}} & 0.071 & 0.041 & 0.037 & -0.007 & -0.044 & -0.063 & -0.043 & -0.101 & -0.072
\end{array}
$$

\begin{tabular}{|c|c|c|c|c|c|c|c|c|}
\hline Deciles: & 0.1 & 0.2 & 0.3 & 0.4 & 0.5 & 0.6 & 0.7 & 0.9 \\
\hline
\end{tabular}

\section{SOUTH}

Dep var: $\log \mathrm{W}_{\mathrm{t}}$ 
Model without regional fixed effects

$$
\begin{array}{cccccccccc}
\log \mathrm{U}_{\mathrm{t}} & -0.097 & -0.067 & -0.057 & -0.024 & -0.001 & -0.018 & 0.062 & -0.002 & -0.001 \\
& (0.7) & (0.8) & (0.7) & (0.4) & (0.1) & (0.3) & (1.1) & (0.1) & (0.1)
\end{array}
$$

Model with fixed regional effects

$\begin{array}{llllllllll}\log U_{t} & 0.317 & 0.114 & 0.081 & 0.069 & 0.050 & 0.046 & 0.160 & 0.068 & 0.106\end{array}$
(1.4)
(0.7)
$(0.6) \quad(0.5)$
$(0.4) \quad(0.4)$
$(1.5) \quad(0.6)$
$(0.4)$

Error Correction Model

$\begin{array}{llllllllll}\log \mathrm{U}_{\mathrm{t}-1} & 0.256 & 0.084 & 0.022 & -0.078 & -0.005 & -0.055 & -0.055 & 0.118 & -0.025\end{array}$
$(0.7)$
$(0.3)$
$(0.1) \quad(0.4)$
$(0.1) \quad(0.3)$
$(0.3) \quad(0.6)$
$(0.1)$

$\begin{array}{llllllllll}\text { DeltaU } & 0.399 & 0.229 & 0.075 & 0.025 & 0.020 & 0.009 & -0.076 & 0.047 & 0.032\end{array}$
(1.3)
(1.2)
$(0.4) \quad(0.2)$
$(0.2)$
$(0.1)$
$(0.5) \quad(0.3)$
$(0.1)$

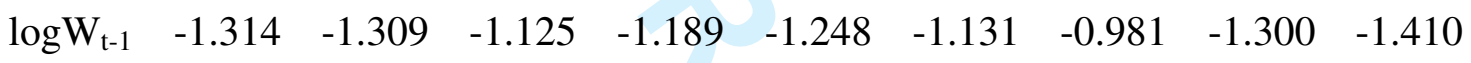

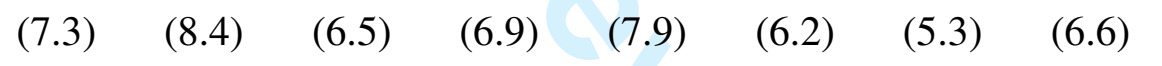

$\eta_{\mathrm{w} . \mathrm{U}}$

$0.195 \quad 0.06$

0.020

Notes: see Table I. 
Table IV: Estimates of the wage curve along the wage distribution by region,

\section{GERMANY}

\section{WEST}

Dep var: $\log \mathrm{W}_{\mathrm{t}}$

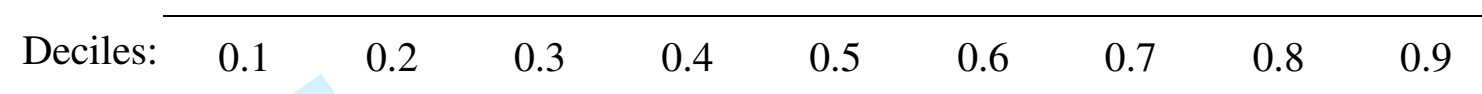

Model without regional fixed effects

$\begin{array}{lllllllllll}\log \mathrm{U}_{\mathrm{t}} & -0.013 & -0.032 & -0.046 & -0.052 & -0.061 & -0.067 & -0.075 & -0.083 & -0.074 \\ & (0.93) & (2.52) & (3.42) & (4.06) & (4.93) & (5.11) & (5.63) & (5.19) & (1.9)\end{array}$

Model with fixed regional effects

$\begin{array}{lcccccccccc}\log U_{t} & 0.009 & -0.01 & -0.009 & -0.004 & -0.005 & -0.020 & -0.015 & -0.023 & 0.267 \\ & (0.23) & (0.34) & (0.4) & (0.12) & (0.21) & (0.6) & (0.47) & (0.47) & (1.22)\end{array}$

Dep var: $\log \mathrm{W}_{\mathrm{t}}-\log \mathrm{W}_{\mathrm{t}-1}$

\section{Error Correction Model}

\begin{tabular}{|c|c|c|c|c|c|c|c|c|c|}
\hline \multirow[t]{2}{*}{$\log U_{t-1}$} & -0.041 & -0.053 & -0.025 & -0.032 & -0.045 & -0.054 & -0.020 & -0.020 & 0.247 \\
\hline & (1.0) & (1.7) & $(0.9)$ & (1.2) & (2.1) & (1.9) & $(0.6)$ & $(0.4)$ & (1.2) \\
\hline \multirow[t]{2}{*}{ DeltaU } & 0.024 & 0.015 & 0.021 & 0.009 & -0.026 & -0.036 & -0.021 & -0.057 & 0.010 \\
\hline & $(0.5)$ & $(0.4)$ & $(0.6)$ & $(0.3)$ & $(0.9)$ & $(0.9)$ & $(0.5)$ & $(1.0)$ & $(0.1)$ \\
\hline \multirow[t]{2}{*}{$\log \mathrm{W}_{\mathrm{t}-1}$} & -0.634 & -0.734 & -0.562 & -0.568 & -0.439 & -0.452 & -0.526 & -0.393 & -0.247 \\
\hline & $(3.8)$ & $(4.3)$ & $(2.7)$ & (3.7) & (2.7) & (3.2) & (3.3) & (2.9) & $(1.1)$ \\
\hline$\eta_{\mathrm{w}, \mathrm{U}}$ & -0.065 & -0.072 & -0.044 & -0.056 & -0.103 & -0.119 & -0.038 & -0.051 & 1.000 \\
\hline
\end{tabular}

\section{EAST}

Dep var: $\log \mathrm{W}_{\mathrm{t}}$ 


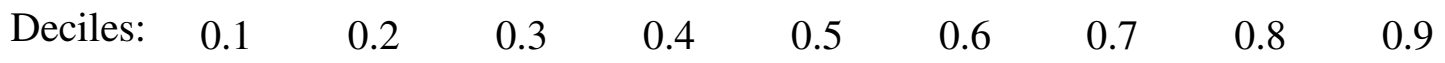
Model without regional fixed effects

$\begin{array}{rccccccccc}\log \mathrm{U}_{\mathrm{t}} & -0.044 & -0.125 & -0.128 & -0.102 & -0.175 & -0.171 & -0.164 & -0.215 & -0.304 \\ & (0.3) & (0.9) & (1.0) & (0.8) & (1.2) & (1.2) & (1.1) & (1.4) & (1.6)\end{array}$

Model with fixed regional effects

$\begin{array}{llllllllll}\log U_{t} & -0.166 & -0.098 & -0.137 & -0.149 & -0.147 & -0.197 & -0.197 & -0.275 & -0.479\end{array}$
(2.3)
(2.2)
(3.3) (3.4)
(4.1) (4.2)
(3.4) (3.2)
(3.5)

Error Correction Model

$\begin{array}{rrrrrrrrrr}\log \mathrm{U}_{\mathrm{t}-1} & -0.236 & -0.158 & -0.143 & -0.108 & -0.125 & -0.105 & -0.085 & -0.236 & -0.329 \\ & (2.6) & (4.5) & (3.9) & (2.8) & (3.6) & (2.5) & (1.4) & (2.1) & (1.6)\end{array}$

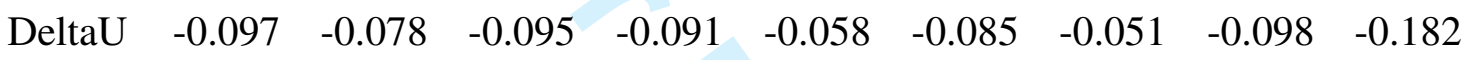
(1.3)
(2.1)
(2.6)
(2.6) (1.6)
(3.2)
(1.2)
(1.3)

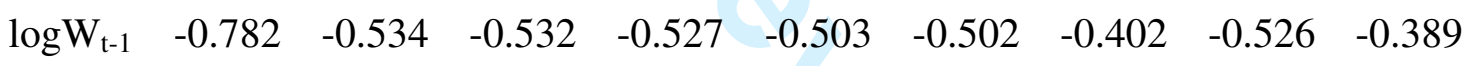

$(4.4)$

(5.1)

(3.9)

(5.2)

(4.0)

(3.3)

(2.8)

(3.7)

(2.7)

$\eta_{\mathrm{w} . \mathrm{U}}$

$\begin{array}{lllllllll}-0.302 & -0.296 & -0.269 & -0.205 & -0.249 & -0.209 & -0.211 & -0.449 & -0.846\end{array}$

Notes: see Table II. 
Figure 1: Participation and unemployment rates by region in non agricultural private sector

Italy

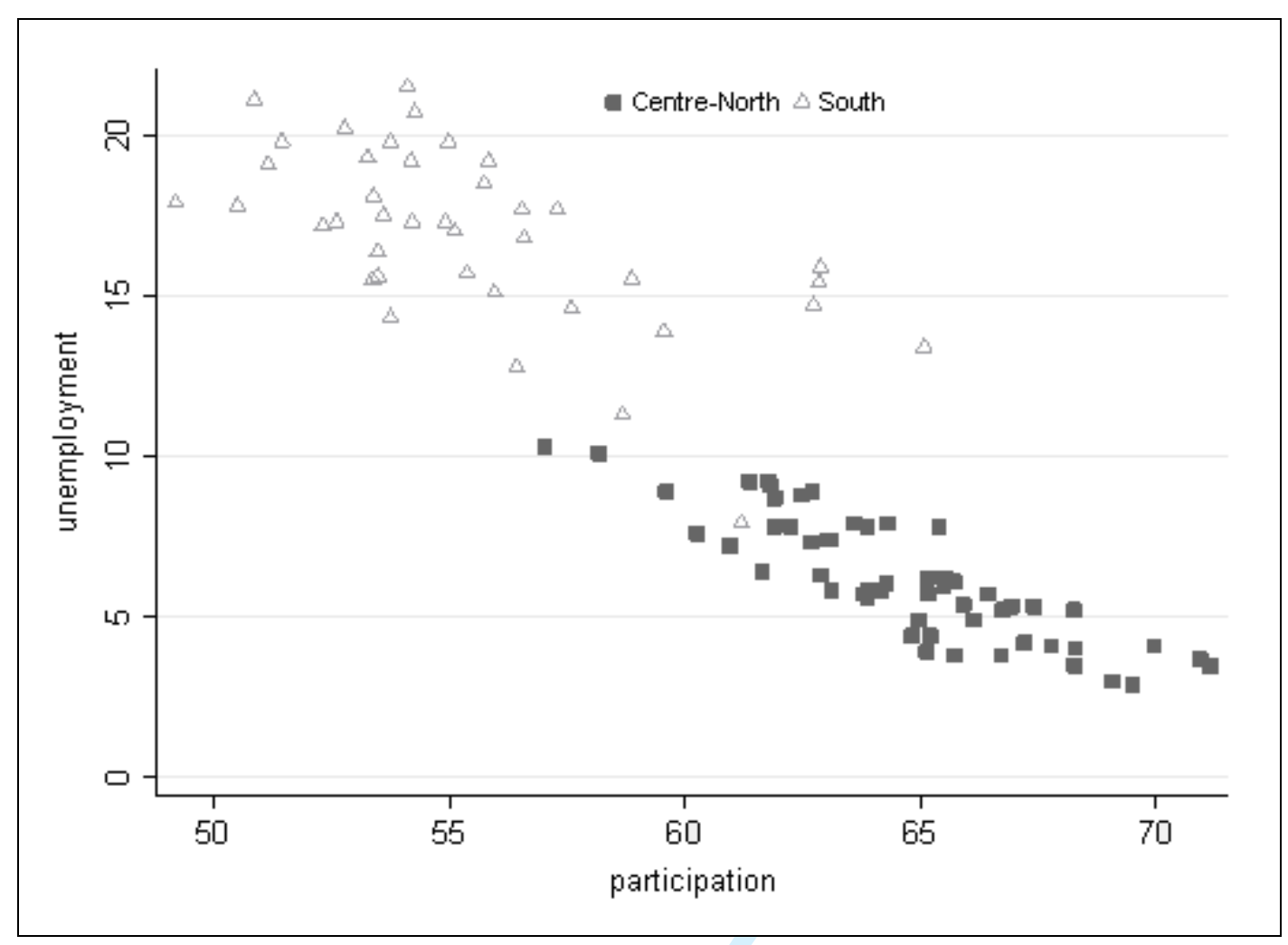


Germany

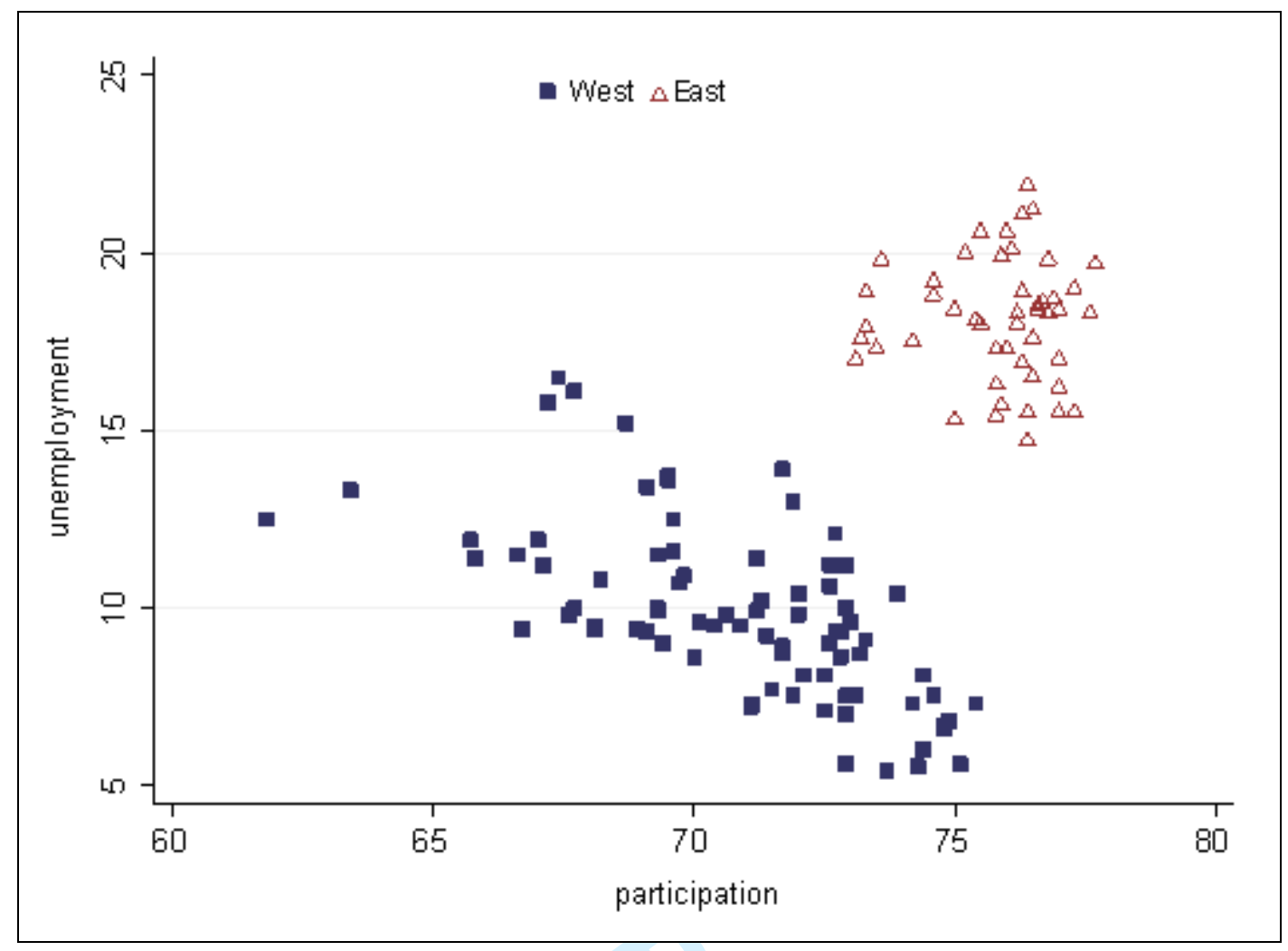


Endnotes:

${ }^{1}$ We thank Uwe Blien, Giovanni Mastrobuoni, Jens Suedekum, participants at the 2006 EALE conference (Prague, Czech Republic), and especially Andrew Oswald as well as three anonymous referees for useful comments. Microdata for Italy have been kindly made available by the Bank of Italy. Claudio Lucifora acknowledges financial support from the Italian Ministry of Research and Education (MIUR) under the PRIN 2006 research project. Part of the paper was written during a research stay by Thomas Zwick at Università Cattolica di Milano financed by the European Commission under the Low Wage and Employment Research Network (LoWER3).

${ }^{2}$ For further details, see section 3.

${ }^{3}$ First, it is proposed to reduce regulations and over generous social benefits. Second, subsidies should be concentrated on regions and sectors with the highest future potential such as the automotive industry and the high technology sector in the regions of the cities of Dresden and Leipzig. Third, workfare programmes such as the so-called "Magdeburger Alternative" should push unemployed into jobs paid at the lower level of regional productivity with additional public transfers in order to secure a decent standard of living.

${ }^{4}$ Compare BANDE et al. (2007) for an analysis of the consequences of similar steps at the end of the 1980s in Spain.

${ }^{5}$ A caveat, is particularly relevant in Italy and its large share of the labour force employed in the underground economy. Whilst the effective size of this non-regular form of employment is not known, its effect on the functioning of regional labour markets might be important. This is an obvious limit in any analysis of the wageunemployment relationship which the present study shares with previous work. 
$\overline{{ }^{6}}$ The figure is based on the data used in section 6 which are described in section 5.2. We regress using OLS regional participation on time dummies, region dummies and the regional unemployment rate.

${ }^{7}$ Note that less than $10 \%$ of the studies on wage curves use instrumental variables to control for endogeneity of the unemployment rate and employ OLS as the estimation technique instead (NIJKAMP and POOT, 2005).

${ }^{8}$ A crucial assumption of these models is that workers can freely move at no cost: workers should in fact be able to move across areas to respond to the different arbitrage conditions given by different combinations of local wages and unemployment. Costless mobility occurs up to the point in which expected utility is equalised across areas.

${ }^{9}$ Note that the "wage curve" view is not necessarily in contradiction with the theory of compensating differentials. While the former describes deviations of unemployment and wages from the permanent features 'within' each area, the latter describes an equilibrium of such permanent features 'between' the different areas.

${ }^{10}$ Equation [3] assumes that mobility flows are equal to zero and that there is no spatial correlation between areas (i.e., $\operatorname{cov}\left(w^{k}, w^{h}\right)=0$ if $k \neq h$, where $k$ and $h$ are regions, ANSELIN, 1988). However, the existence of spill-over effects between areas close to each other cannot be excluded a priori. We tried to assess spill-over effects by taking out migrants between regions from the sample in Germany. The results did not change, however, compare AMMERMÜLLER et al. (2008).

${ }^{11}$ Note that this specification of the unemployment rate (in level and change) is a simple re-parameterisation of the model outlined in equation [4].

${ }^{12}$ As discussed in BLANCHARD and KATZ (1999) and MONTUENGA and RAMOS (2005), this is particularly relevant for many European countries, including Italy and 
Germany.

${ }^{13}$ In this case the long run elasticity of wages to local unemployment is $\eta_{w, U}=\gamma_{1} / a$.

${ }^{14}$ Since the survey is usually run every two years, we used the 1991, 1993, 1995, 1998, 2000, 2002 and 2004 surveys. Data on wages and workers' characteristics are available for the years of the survey and not for the other years in the range.

${ }^{15}$ Italy is actually divided into 20 administrative regions, characterised by quite different sizes. Given the relatively low number of observations in SHIW for the smallest regions (less than 50 observations per year), the empirical analysis was based on 19 regions, with Valle d'Aosta aggregated with Piemonte.

${ }^{16}$ In micro-data for Germany net income is given in intervals. We take midpoints of the categories. The problem of earnings information given in categories is less severe than it first seems. First, categories are quite small (e.g. 24 income categories). Second, individuals usually don't know exactly the monthly income and therefore, measurement error should not be much higher than in other data sets.

${ }^{17}$ For both countries we also consider the actual number of hours worked, including overtime. BLACK and FITZROY (2000) and HART (2003) show that estimates of the wage curve may change when only standard hours are considered. Unfortunately, our data do not allow to separate overtime from standard hours. Furthermore, for Germany we restrict hourly earnings to a maximum of $154 €$ and a minimum of $1.02 €$. The upper limit affects only very few observations due to the categorical income variable and the lower limit affects less than 0.5 percent of the sample.

${ }^{18}$ An important reason for the inappropriateness of annual earnings is that working hours tend to decline in recessions (CARD, 1995). Still, most empirical estimations of the wage curve are on the basis of annual or monthly data (NIJKAMP and POOT, 
2005).

${ }^{19}$ In the Italian data-set we have also a direct measure of work experience. Using the latter instead of potential experience does not significantly change our main results.

${ }^{20}$ More specifically, we control for gender, education, experience and tenure. Estimates refer to hourly individual wages as dependent variable. Similar results (available upon request) were obtained using monthly wages.

${ }^{21}$ It is important to stress that equation [5], given the presence of a lagged dependent variable on the right-hand-side, still implies that the equation is in levels - as the theory of the wage curve suggests - and that the error term is not altered by the transformation.

${ }^{22}$ In column 6, the specification reported in equation [5] is estimated.

${ }^{23}$ For example, BLANCHFLOWER and OSWALD (1994a) used ISSP data for the 1986-89 period and estimated the wage curve using cell means; CANZIANI (1997) also used our data-set for a shorter period (1989, 1991 and 1993) and she estimated a 2-stage model without including regional fixed effects in the second stage; MONTUENGA et al. (2003, 2006) estimated a wage curve using ECHP data for Italy (and four other EU countries) for the 1994-96 period. Note also that the wage curve estimates for Italy reported in BLANCHFLOWER and OSWALD (1994a) are equal to -0.1 (as the "empirical rule" suggests) but they are not statistically significant. In all the other contributions cited the elasticity of wages to unemployment is negative and statistically significant, but its size is generally relatively small (between 0.04 and 0.07 in absolute value)

${ }^{24}$ This result didn't emerge in our previous work (see LUCIFORA and ORIGO, 1999) and in other studies on Italy using a dynamic specification because they considered only the Eighties and the first years of the Nineties, a period characterised by continuous 
growth of real wages.

${ }^{25}$ BALTAGI and BLIEN (1998) and BALTAGI et al. (2000) also find large differences between the estimation methods but stronger effects in their preferred first-differenced two stage least square estimations.

${ }^{26}$ For both Italy and Germany, the Hausman test did not reject the hypothesis of exogeneity of the unemployment variable. This might however also be a consequence of our instrument being weak.

27 All these studies try also to control for spatial correlation, which may be important when there are spillover effects between neighbouring regions. For example, a local shock that increases unemployment may not lead to lower wages in that region if the employers fear that workers can move and find a job in other neighbouring labour markets. To correct for cross-sectional dependence in the case of Germany, BÜTTNER (1999) and LONGHI et al. (2006) consider spatially transformed error terms, while ELHORST et al. (2007) develop a spatial panel estimator. All these studies are based on a very high number of regions (327 for West Germany, 114 for East Germany), hence commuting for work reasons may be very likely. Since our analysis is based on larger regions, workers mobility is much lower and spatial interaction between local labour markets is less relevant.

${ }^{28}$ We estimated the wage curve also for different age groups. Results are similar to those obtained at the aggregate level. Estimates are available upon request.

${ }^{29}$ Their results also differ strongly depending on the estimation approach. They use different data sets with a much finer regional classification, different time periods, and a slightly different estimation approach always aggregating wages and individual characteristics on the regional level instead of estimating individual wage regressions in 
the first step.

${ }^{30}$ More specifically, the dependent variables of the second stage are now the regional fixed effects obtained from the first step quantile regressions on individual micro-data, in which for each decile we controlled for the same worker characteristics used in the previous OLS estimates. 